
\title{
THE FIRST BOOK
}

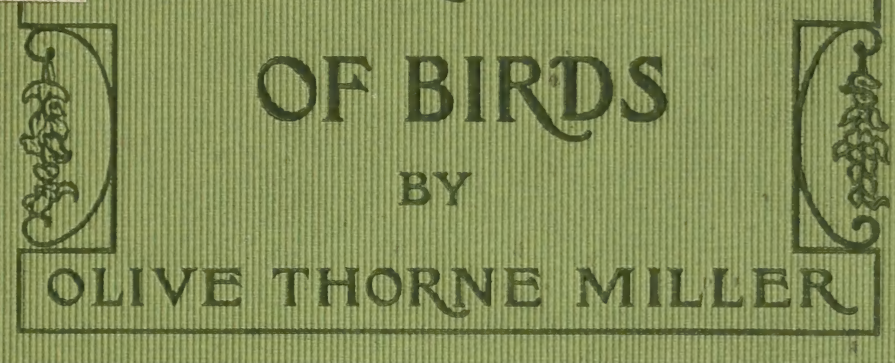








\section{¿by Oline Tharne fttiller.}

BIRD-WAYS. I6mo, \$1.25.

IN NESTING TIME. $16 \mathrm{mo}, \$ \mathrm{I} .25$.

LITTLE BROTHERS OF THE AIR. I6mo, $\$ 1.25$.

A BIRD-LOVER IN THE WEST. I6mo, \$1.25. FOUR-HANDED FOLK. Illustrated. $16 \mathrm{mo}$, $\$ 1.25$.

UPON THE TREE-TOPS. Illustrated. 16mo, $\$ 1.25$.

THE FIRST BOOK OF BIRDS. Illustrated.

Square $12 \mathrm{mo}, \$ \mathrm{I} .00$.

HOUGHTON, MIFFLIN AND COMPANY, Boston ANd New York. 



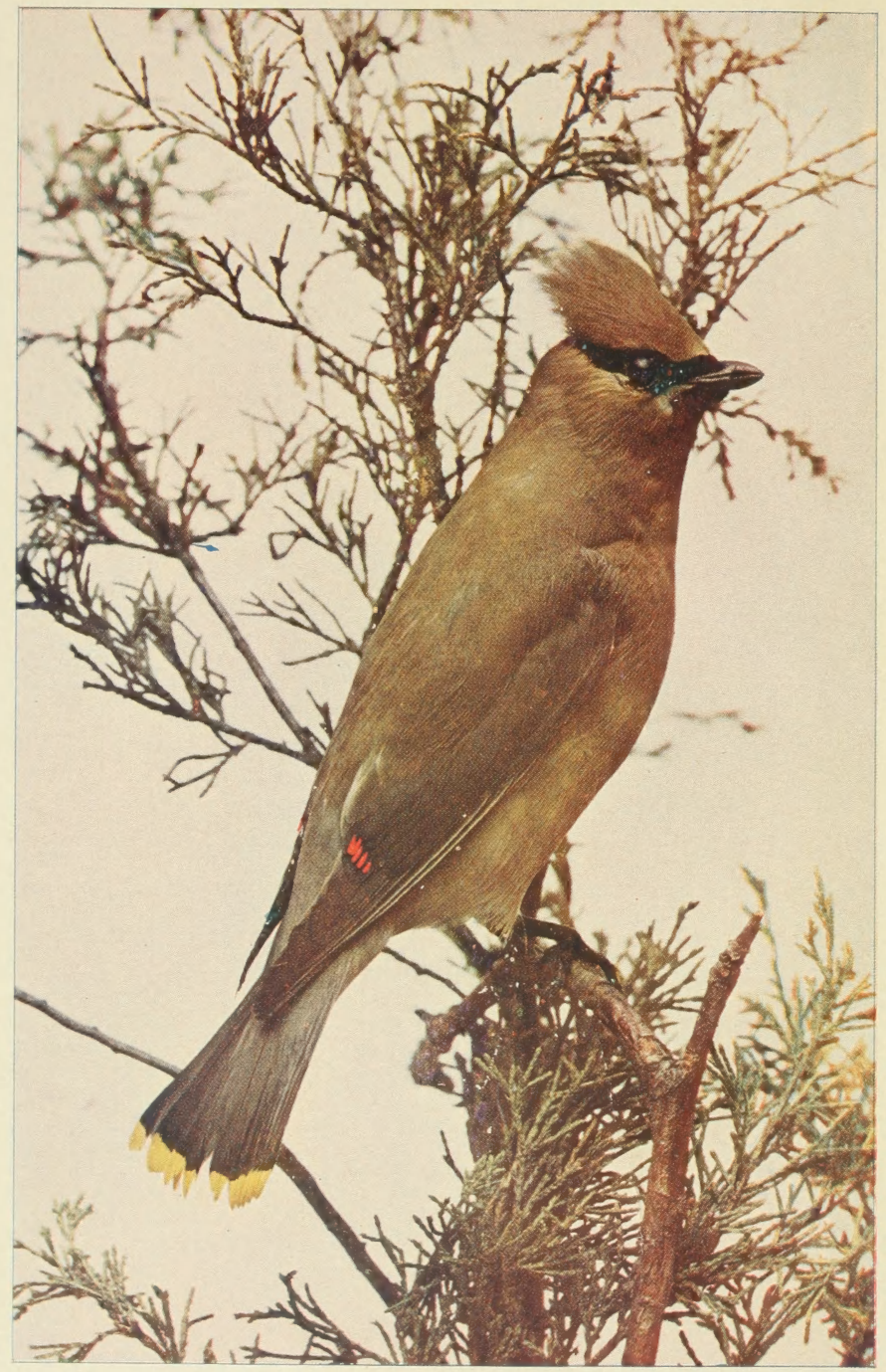


Cedar-bird 



\section{9 Birds}

\section{THE FIRS'T BOOK} OF BIRDS/

\section{BY OLIVE THORNE MILLER}

WITH EIGHT COLORED AND TWELVE

PLAIN PLATES AND TWENTY

FIGURES IN THE

TEXT

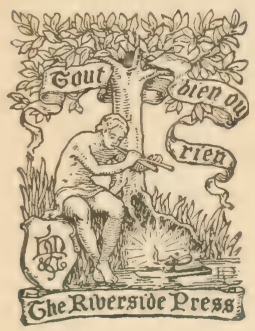

BOSTON AND NEW YORK

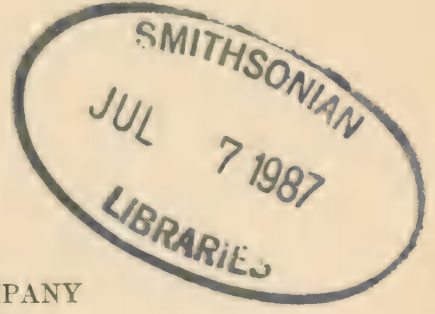
HOUGHTON, MIFFLIN AND COMPANY Che lfibergion press, Cambrione 
COPYRIGHT, I $\delta 99$, BY H. M. MILLER

ALL RIGHTS RESERVED 


\section{PREFACE}

This book is intended to interest young people in the ways and habits of birds, and to stimulate them to further study. It has grown out of my experience in talking to schools. From the youngest kindergarten scholar to boys and girls of sixteen and eighteen, I have never failed to find young people intensely interested so long as I would tell them about how the birds live.

Some of the results of these talks that have come to my knowledge have been astonishing and far-reaching, such as that of one boy of seven or eight, who persuaded the village boys around his summer home to give up taking eggs and killing birds, and watch them instead, and who was dubbed "Professor" by his eager followers. The effect has always been to make children love and respect the living bird.

It has therefore seemed to me that what is needed at first is not the science of ornithology, 
- however diluted, - but some account of the life and habits, to arouse sympathy and interest in the living bird, neither as a target nor as a producer of eggs, but as a fellow-creature whose acquaintance it would be pleasant to make.

With this purpose in view I have expanded my "Children's Talks" into this little book, to be used as an introduction to one of the most fascinating and delightful of studies.

I hope it is unnecessary to say that I have been careful to have the latest and the best authorities for the statements made, and I take pleasure in presenting a list of them :-

On Structure: Dr. Elliott Coues, of Washington, D. C.; Professor Headley, of Haileybury College, England; Mr. Lucas, Curator of Comparative Anatomy, of the National Museum.

On Moulting: Mr. Witmer Stone, of Philadelphia Academy of Sciences.

On Color: Professor Newton, of Cambridge University, England.

On Food: Professor Beal, of Biological Sur- . vey, United States Department of Agriculture; Mr. Forbush, of Massachusetts State Board of Agriculture; Mr. Forbes, Director Illinois State 
Laboratory of Natural History; Dr. C. Hart Merriam, Chief of Biological Survey, United States Department of Agriculture.

On Migration: Mr. William Brewster, President American Ornithologists Union; Mr. Frank M. Chapman, of American Museum of Natural History, of New York.

On Sleep: Rev. Leander Keyser; Mr. J. Newton Basket.

On Language: Mr. John Burroughs; Professor Hameric, of Peabody Conservatory of Music of Baltimore; Mr. Leverett M. Loomis, of California Academy of Sciences.

OLIVE THORNE MILLER. 



\section{CONTENTS}

CHAP.

PAGE

I. WHAT YOU WANT TO KNOW . . . . . 1

II. When theY COME IN THE SPRING . . . ;

THE NESTLING

III. The Bird's Home . . . . . . . 9

IV. The BABY BiRD . . . . . . . . 13

V. HOW HE IS FED. . . . . . . . . 17

VI. His first SuIt . . . . . . . 21

VII. How he changes his Clothes . . . 25

VIII. His first Flight . . . . . . . 29

IX. His Education . . . . . . . . . . 33

X. Some of his Lessons . . . . . . . . 37

\section{THE BIRD GROWN UP}

XI. The Bird's Language . . . . . . 43

XII. What he eats . . . . . . . . . 48

XIII. More about his Food . . . . . . 52

XIV. WhERE HE SLEePS . . . . . . . 57

XV. His Travels . . . . . . . . 61

XVI. His Winter Home . . . . . . . 66

XVII. His Family and Friends . . . . 70

XVIII. His Kindness to others . . . . . 74

XIX. His Affections. . . . . . . . . 78

XX. His Intelligence . . . . . . . 83

HOW HE IS MADE

XXI. His Bopy . . . . . . . . . 91

XXII. His Beak and Tongue. . . . . . 95

XXIII. His Exes ANd EARs . . . . . . 100

XXIV. His Feet and Legs . . . . . . 105

XXV. His Wings and Tall . . . . . . 109 
XXVI. His Dress . . . . . . . . . 114

XXVII. Different COlored SuITS . . . . . 118

\section{HIS RELATIONS WITH US}

XXVIII. HOW HE WORKS FOR US . . . . . . 12.5

XXIX. How to attract him about our Homes • 131

XXX. How to sTUdy HIM . . . . . . . 136

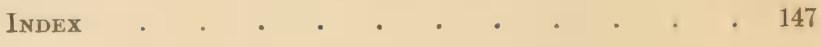




\section{LIST OF FULL-PAGE ILLUSTRATIONS}

PAGE Yellow-throated Vireo and Nest . . . . . 4

American Goldfinch (colored) . . . . . . 14

Yolng WOOD ThRESH . . . . . . . . . 22

Black and White Warbler (Male and Female) . 26

Baltimorf Oriole and Nest (colored) . . . 34

Flicker . . . . . . . . . . . 38

Bltebird (colored) . . . . . . . . . . . 44

BLUE JAY . . . . . . . . . . . . . 54

INDIGO-BIRD . . . . . . . . . . . . 62

Scarlet Tanager (colored) . . . . . . 74

House WTREN . . . . . . . . . . 80

CHEWINK, OR ToWHEE . . . . . . . . . 92

Redstarts (Female on Nest) (colored) . . . 100

Lesser Yellowlegs . . . . . . . 106

CAtbird . . . . . . . . . . . . 114

American Robin (colored) . . . . . . 120

Black-CApped Chickadefs . . . . . . 126;

CARDiNal . . . . . . . . . . . . . $1: 22$

MeadowlakK (colored) . . . . . . . . 140 



\title{
THE FIRST BOOK OF BIRDS
}

\author{
I \\ WHAT YOU WANT TO KNOW
}

Birds seem to be the happiest creatures on earth, yet they have none of what we call the comforts of life.

They have no houses to live in, no beds to sleep on, no breakfast and dinner provided for them.

This book is to tell something about them; where they live and what they eat, where they sleep, how they get their beautiful dress, and many other things. But no one can tell all about their lives and habits, for no one knows all their ways.

Men who study dead birds ean tell how they are made, how their bones are put together, and how many feathers there are in the wings and tail. Of course it is well to know these things. But 
to see how birds live is much more interesting than to look at dead ones.

It is pleasant to see how mother birds build their nests, and how they take care of their nestlings. It is charming to see the young ones when they begin to fly, and to know how they are taught to find their food, and to keep out of danger, and to sing, and everything young birds need to know.

Then when they are grown up, it is interesting to find out where they go in winter, and why they do not stay with us all the year round.

One who goes into the field to watch and study their ways will be surprised to find how much like people they act. And after studying living birds, he will never want to kill them. It will seem to him almost like murder. 


\section{II}

WHEN THEY COME IN THE SPRING

In the long, cold winter of the New England and Middle States, not many birds are usually seen. In the cities there is always the English sparrow, and in the country, now and then a chickadee, or a woodpecker, or a small flock of goldfinches.

But very early in the spring, long before grass is green, even while snow is on the ground, the birds begin to come.

Some morning a robin will appear, standing up very straight on a fence or tree, showing his bright red breast and black cap, flirting his tail, and looking as if he were glad to be back in his old home.

Then perhaps the same day will come the hoarse chack of a blackbird, and two or three will fly over and alight in a big bare tree, looking, it may be, for a good place to build a bird city.

Soon will be heard the sweet little song of the song sparrow or the bluebird, and then we shall 
know that summer is coming, for these are the first birds of spring.

Day after day, as the snow melts away and the sunshine grows hotter, more birds will come. One day a catbird or two, another day an oriole in black and gold, and another day a pert little wren. So it will go on, till by the time June comes in, all our birds will be back with us, very busy, hopping around in our bushes and trees, making their nests all about, and singing the whole day long.

Almost the first thing every bird thinks of, when he comes to us, is making the nest. For summer is the only time in his life that a bird has a home.

He does not need a house to live in. He cares nothing for a roof to cover him, because when the sun is hot, he has the broad green leaves on the trees to shade him. And when it rains his neat feather coat is like a waterproof that lets the drops run off, leaving him warm and dry under it.

He does not need a dining-room, because he eats wherever he finds his food, and he wants no kitchen, because he prefers his food raw.

He has no use for a bedroom, because he can sleep on any twig; the whole world is his bedroom. 


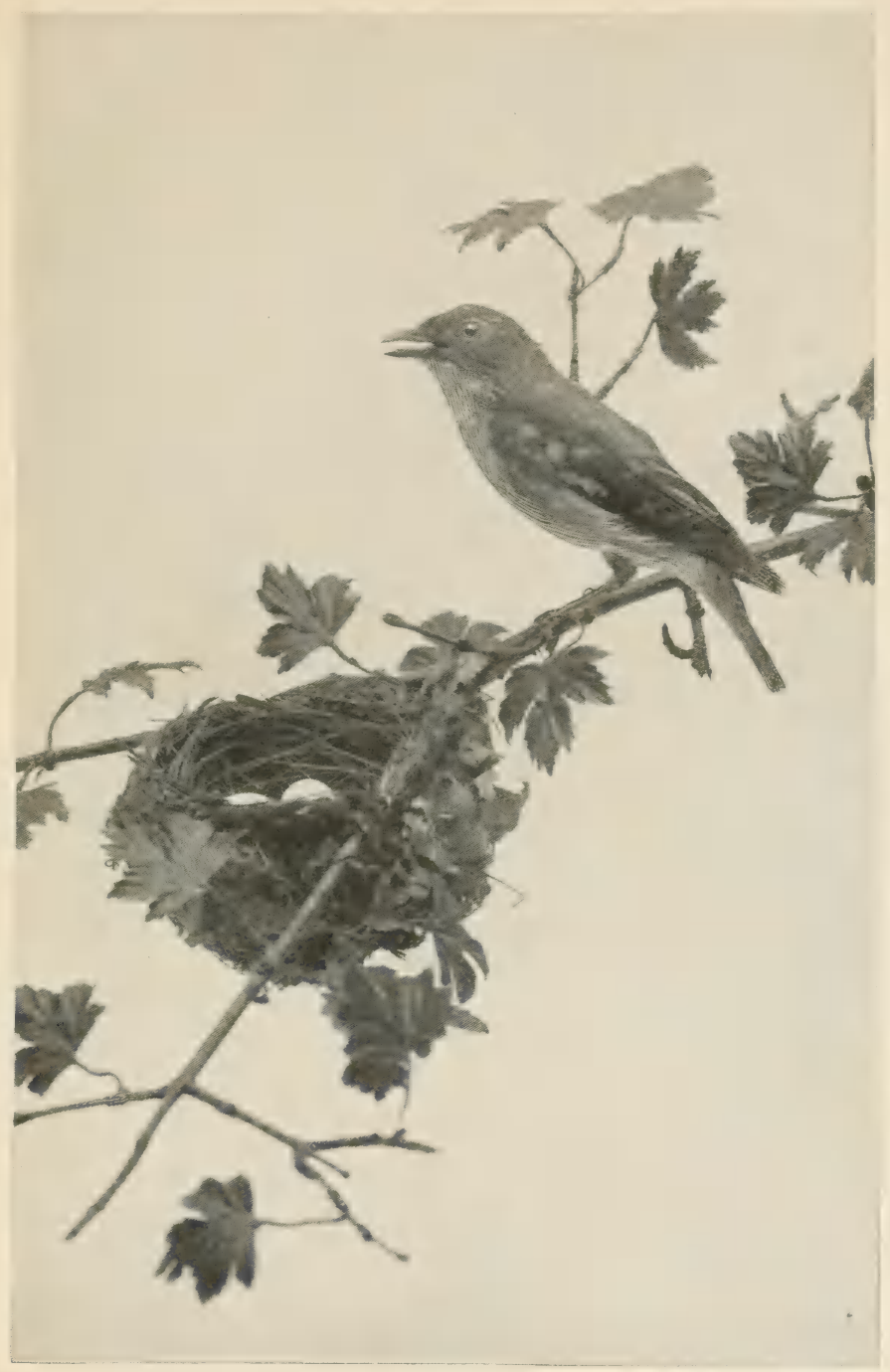

YELLOW-THROATED VIREO ANI NEST 

He cares nothing for closets and bureaus, because he has only one suit of clothes at a time, and he washes and dries that without taking it off.

He wants no fire to keep him warm, for when it is too cold he spreads his wings and flies to a warmer place. A bird has really no need of a house, - excepting when he is a baby, before his eyes are open, or his feathers have come, or his wings have grown. While he is blind, naked, and hungry, he must have a warm, snug cradle.

So when the bird fathers and mothers come in the spring the first thing they do is to find good places and build nice cradles, for they are very fond of their little ones. They spend the spring and summer in working for them, keeping them warm, feeding them till they are grown up, and then teaching them to fly and to take care of themselves, so that when summer is gone they will be ready to go with the other birds to their winter home. 

THE NESTLING 



\section{III \\ THE BIRD'S HOME}

EACH bird mother has her own way of making the nest, but there is one thing almost all of them try to do, and that is to hide it.

They cannot put their little homes out in plain sight, as we do our houses, because so many creatures want to rob them. Squirrels and snakes and rats, and some big birds, and cats and many others, like to eat eggs and young birds.

So most birds try, first of all, to find good hiding-places. Some tiny warblers go to the tops of the tallest trees, and hide the nest among the leaves. Orioles hang the swinging cradle at the end of a branch, where cats and snakes and naughty boys cannot come. Song sparrows tuck the little home in a tuft of weeds, on the ground, and bobolinks hide it in the deep grass.

After a safe place is found, they have to get something to build of. They hunt all about and gather small twigs, or grass stems, or fine 
rootlets, and pull narrow strips of bark off the grapevines and the birch-trees, or they pick up strings and horsehairs, and many other things. Robins and swallows use mud.

As they go on building, the mother bird gets inside and turns around and around to make it fit her form, and be smooth and comfortable for her to sit in.

When a nest is made, it must be lined. Then some birds go to the chicken yard, and pick up feathers, and others find horsehairs. Some of them pull off the soft down that grows on plants, or get bits of wool from the sheep pasture, or old leaves from the woods, and make it soft and warm inside.

Some bird homes are only platforms, where it seems as if the egg's must roll off, and others are deep burrows, or holes in the ground, where no one can get in. Some are dainty baskets hung between two twigs, and others are tiny cups of felt with lichens outside.

Each species of bird builds in its own way. There are as many different ways to make nests as there are kinds of birds to make them.

Then after all the trouble birds have taken to build a nest, they seldom use it a second time. If a pair have two broods in a season, they almost always build a new one for each family. 
A few birds, such as eagles, owls, and sometimes orioles, and others, repair the home and use it again, and woodpeckers sometimes nest in the old holes. But generally, after the young birds have flown, we may be sure the nest will not be wanted again.

When the nest is finished, the eggs are laid in it, one by one. We all know how pretty birds' egg's are. Some are snowy white, some are delicate pink, and some blue. Many have tiny dots and specks on them, and a few are covered with queer-looking streaks and lines. But pretty as they are, I think no one would be so cruel as to take them away from the poor little mother, if he remembered that her young ones are inside them, and that she loves them as his own mother loves him.

I have heard people say that birds do not care for their eggs. Let me tell you what a little chickadee mother did when a man tried to steal the eggs out of her nest.

The nest was in a hole in an old stump, and the man could not get his hand in, so he had to take them out one at a time with a little scoop.

At first the mother flew at him and tried to drive him away. Then chickadees and other birds who lived near came to help her. All flew about his face with cries, so that he had to 
use one hand to keep them away from his eyes. But still he went on taking out the eggs.

At last the little mother was so wild with grief that she dashed into the hole and sat there in the doorway, right before his face. He could not get another egg without hurting her, and he was ashamed to do that.

This was as brave in the tiny creature as it would be for a human mother to throw herself before a fierce, hungry tiger. Do you think she did not care for her eggs? 
A BABY bird, as you know, always comes out of an egg. And beautiful as these eggs are, they are most interesting when you think that each one holds a tiny bird.

Eggs are not all alike, of course. One the size of a bean is large enough to hold a hummingbird baby, till it is old enough to come out. But the young ostrich needs a shell nearly as big as your head. So there are all sizes of eggs to fit the different sizes of birds.

If you should break a fresh egg you would not see a bird, for it would not be formed at that time. After the egg is laid in its soft bed, it has to be kept warm for many days, and that is why the mother bird sits on her nest so quietly. She is keeping the eggs warm, so that the little ones will form and grow, till they are as big as the shells can hold.

While the mother is sitting her mate does all he can to help, though each species has its own 
way. The blue jay brings food to his mate, so that she need not leave the nest at all, and many others do so. But the kingbird father simply watches the nest to protect it while the mother goes for food. A redstart gets into the nest himself, to keep the eggs warm while his mate is gone, and a goldfinch coaxes his mate to go off with him for a lunch, leaving nest and eggs to take care of themselves.

Another thing the father birds do is to sing. This is the time when we hear so much bird song. The singers have little to do but to wait, and so they please themselves, and their mates, and us too, by singing a great deal.

When the little birds begin to be cramped, and find their cradle too tight, they peck at the shell with a sort of tooth that grows on the end of the beak, and is called the "egg tooth." This soon breaks the shell, and they come out. Then the mother or father carefully picks up the pieces of shell, carries them off, and throws them away, leaving only the little ones in the nest. Perhaps you have found these broken shells on the ground sometimes, and could not guess how they came there. When the birdlings break out of their prison they do not all look the same. Ducks and geese and chickens and quails, and other birds who live on the 
Ameriann Goldfinch 



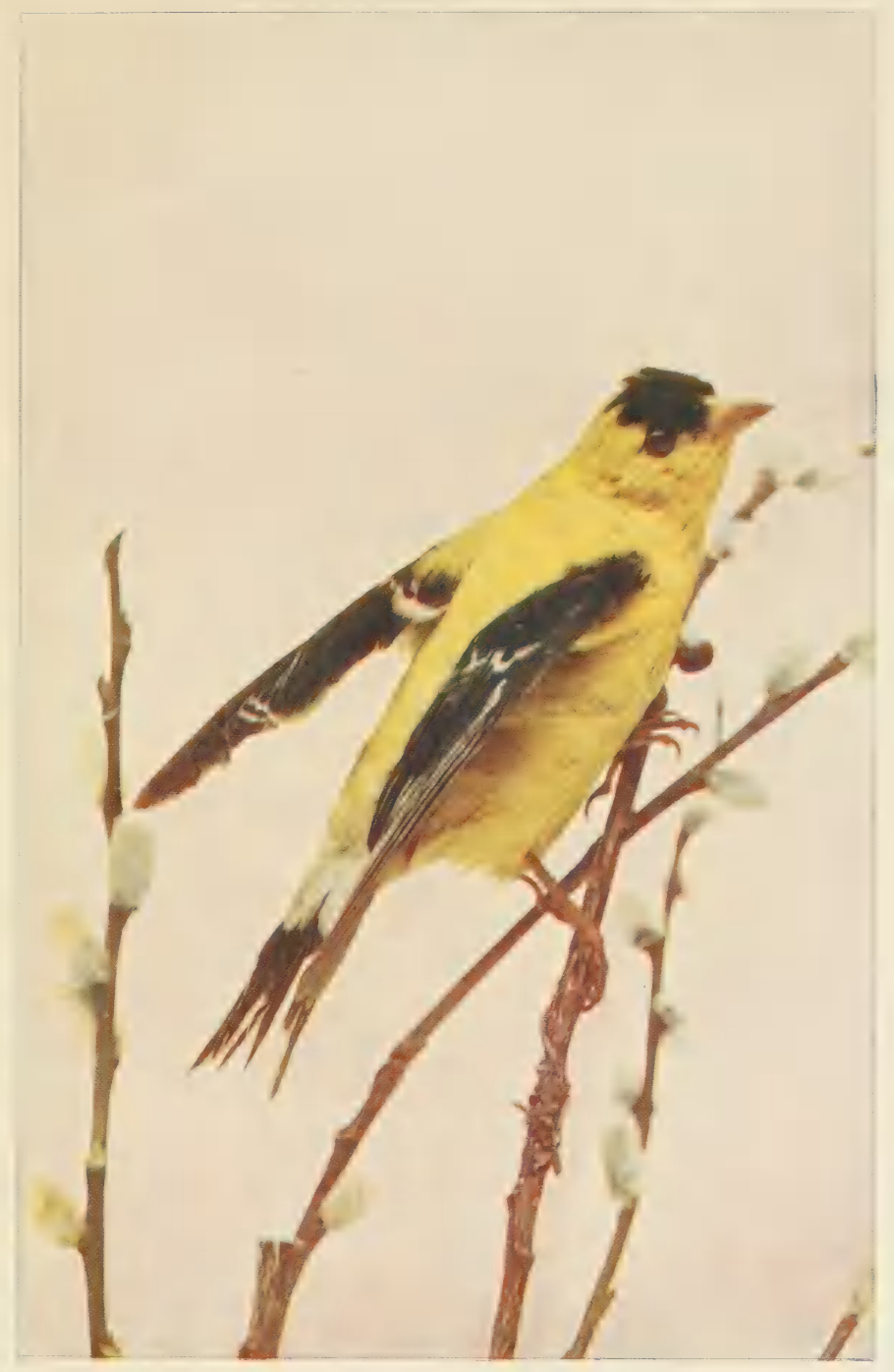



ground, as well as hawks and owls, are dressed in pretty suits of down. They have their eyes open, and the ground birds are ready to run about at once.

A man who studied birds, once saw a young duck get its first suit of down. He picked up the egg just as the little bird inside was trying to get out. In a few minutes the shell fell apart, and out stepped the duckling on his hand. It seemed to be covered with coarse black hairs, which in a moment began to burst open, one by one, and out of each came a soft fluff of down. So in a few minutes, while the man stood there and held him, the little duck was all covered with his pretty dress.

But most birds hatched in nests in trees and bushes, like robins and bluebirds, are very different. When they come out of their shells they are naked, have their eyes shut, and look as if they were nearly all mouth. A young hummingbird looks about as big as a honey bee, and a robin baby not much bigger than the egg'shell he came out of.

They lie flat down in the nest, seeming to be asleep most of the time. All they want is to be warm and to be fed.

To keep them warm, the mother sits on them a great part of the time, and for the first few 
days of their lives, the father often brings most of the food. Sometimes he gives it to the mother, and she feeds the little ones. But sometimes she gets off the nest, and flies away to rest, and get something to eat for herself, while he feeds the nestlings.

There is one bird father who - it is thought - never comes to the nest, either to watch the eggs or to help feed the nestlings. That is our hummingbird, the ruby throat.

We do not know the reason he does so, and it is not fair to say hard things about him until we do. It may be that he thinks his shining ruby would show the hiding-place of the nest, or it may be that the little mother is not willing to have any help. I think this last is the real reason, for she has a great deal of spirit, and always drives away others from her feedingplaces.

Young birds grow very fast, and soon feathers begin to come out all over them. They are not very pretty at this time. 


\section{V \\ HOW HE IS FED}

Soon after the young bird comes out of the egg, he begins to be hungry. All day long, whenever the father or mother comes near, he opens his great mouth as wide as he can, to have it filled, and the moment he gets his voice he cries for food.

Then the old birds have to work hard. Three or four hungry nestlings can keep both father and mother busy from morning till night, hunting for caterpillars and beetles and grubs and other things to feed them. It seems as if the little fellows never could get enough to eat. Fach swallow baby wants seven or eight hundred small flies every day, and a baby robin needs more earthworms in a day than you can hold in your hand at once.

At this time you will see robins hunting over the lawn, and carrying great beakfuls of worms up to the nest. Bluebirds you will find looking in the grass, and sparrows hopping about on the 
ground, all seeking soft worms and grubs and insects for the nestlings; and they are so busy they do not get much time for singing.

At this time the orioles go all over the orchard trees looking for tiny worms, and little warblers seek them under every leaf.

Woodpeckers find the insects hidden behind the bark of trees, by cutting holes through it. Chickadees and nuthatches pick the tiniest insect eggs out of the crevices, and flickers hunt everywhere for ants.

As soon as one of the old birds has his mouth full, he flies to the nest to feed it out.

But not all birds feed in the same way. A robin just drops the big earthworm, or a part of one, into the gaping baby mouth. Many other birds do so also. Sometimes, when an insect is too big or too hard, they beat it till it is soft, or break it up before giving it to a little one.

But hummingbird mothers and flicker mothers have a different way. When they collect the food they swallow it, as if they wanted it for themselves. Then they go to the nest, and jerk it up again in mouthfuls, and feed the nestlings. This is called "feeding by regurgitation," or "throwing up."

The way they give the food is very curious. They push their long beaks into the nestling's 
throat, and poke the food far down; so the young one does not even have the trouble of swallowing.

This looks as if it must hurt, but the nestling seems to like it, and is always ready for more. The pigeon mother lets the young one poke his beak down her throat, and get the food for himself.

If the food is hard, like corn, birds who feed in this way let it stay in the crop till it is soft and better fitted for tender throats, before they give it out.

It is comical to see a nest full of little birds when the father or mother comes with food. All stretch up and open their big mouths as wide as they can, and if they are old enough, they cry as if they were starving.

Some birds bring food enough for all in the nest, every time they come. A cedar-bird, feeding wild cherries, brought five of them every time, one for each of the five nestlings. One cherry was held in his mouth, but the other four were down his throat, and had to be jerked up one by one.

Other birds bring only one mouthful at a time, and when there are five or six in the nest, they have to make as many journeys before all are fed. 
Some persons who have studied birds think that each nestling is fed in its turn; but they look so much alike, and are so close together, that it is hard to tell, and I am not sure that it is so.

I will tell you a story I have heard about feeding little birds. A child picked up a young goldfinch who had fallen out of the nest. He took him home and put him into the canary's cage, which was hanging on the front porch.

Soon the family heard a great noise among the birds, and went out to see what was the matter. The baby goldfinch had hopped on to a perch in the cage, and seemed to be afraid to come down, though the old birds had brought food for him, and were calling him to take it.

The canary looked on a while, and then all at once he flew to the wires and took the food from the birds outside; then he went back to the perch beside the little one and gave it to him. This he did many times.

The next day another young goldfinch was picked up and put in the cage, and the canary took food from the parents and fed both.

After a few days the old birds came with a third little one, and as all were now old enough to $\mathrm{fly}$, the cage door was opened, and they all flew away. 


\section{I}

\section{HIS FIRST SUIT}

Some birds that live on the ground - as I told you - have dresses of down to begin with. These little fellows have no warm nest to stay in, but run around almost as soon as they come out of the egg. Young ducks and geese wear this baby suit for weeks, before they begin to put on their feather coats.

Young birds that spend most of their time in the water, like grebes, and others that live in a cold country, have the down very thick and fine, like heavy underclothes, to keep them dry and warm.

Birds whose home is underground, like the kingfisher, or in the trunk of a tree, like the woodpecker, have hardly any down at all. They need no baby clothes in their warm cradles.

Robins and most other song birds have only a little down on them, and very soon the feathers begin to grow.

When the tiny quills push themselves up, they 
look like little white pins sticking out all over. Each bit of down grows out of a little raised place on the skin that looks like a pimple, and the feather comes out of the same.

As the feather grows, the bit of down clings to it till it is broken off. Sometimes it holds on till the feather is well out. We can often see down sticking to a young bird's feathers.

The little feathers grow very fast, and before he is ready to fly a young bird is well covered. Birds hatched with their eyes open, and already dressed, who have to run and fly very soon, get their wing feathers early; but birds who live many days in the nest, like robins and bluebirds, do not get theirs till they are nearly grown.

The tail feathers are the last to come to full length, and you will notice that most birds just out of the nest have very dumpy tails.

A bird's first suit of feathers is called his nestling plumage. In some families it is just like the dress of the grown-up birds, but in others it is not at all like that. It is usually worn only a few weeks, for the young one outgrows it, and needs a new and bigger one before winter.

When a bird is fully dressed, his body is entirely covered, and it looks as if the feathers grew close to each other all over him. But it is not so. The feathers grow in patterns, called 


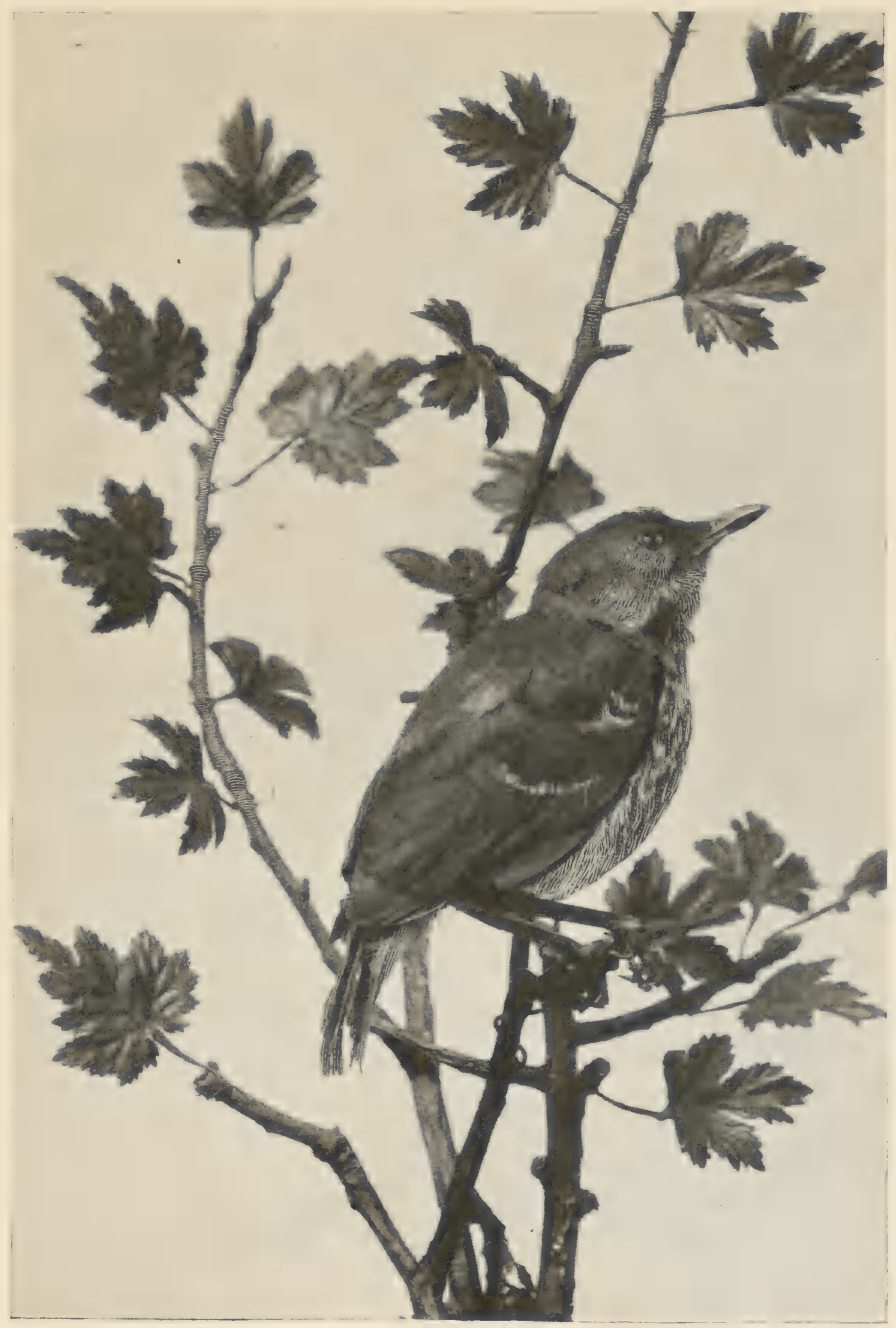

YOUNG WOOD THRUSH 

"feather tracts," with spaces of bare skin between them. These bare places do not show, because the feathers lap over each other and cover them.

The pattern of the feather tracts is not the same in all birds. A few birds of the Ostrich family have feathers all over the body.

There is another curious thing about the nestling plumage. You would expect a young bird to look like his father or mother; and some of them do. Many nestlings are dressed exactly like their mothers; and not until they are a year old do the young males get a coat like their father's. Some of them, indeed, do not have their grown-up suits for two or three years.

Then, again, many young birds have dresses different from both parents. Young robins have speckled breasts, and spots on the shoulders, which the old birds have not.

When the father and mother are dressed alike, as the song sparrows are, the young birds generally differ from both of them. When the father and mother are different, like orioles or bluebirds, the young are usually like the mother the first season. In some cases the father, mother, and young are almost exactly alike.

Birds who live on the ground need dresses of dull colors, or they would not be very safe. The 
ostrich mother, who makes her nest in plain sight on the sand, is dressed in grayish brown. When she sits on the eggs, she lays her long neck flat on the ground before her; then she looks like one of the ant-hills that are common on the plains of Africa, where she lives.

The South American ostrich, or rhea, fluffs out her feathers and looks like a heap of dry grass. The male ostrich is dressed in showy black and white, and he stays away all day, but takes care of the nest at night, when his striking colors cannot be seen. 


\section{VII}

\section{HOW HE CHANGES HIS CLOTHES}

IT takes a bird weeks to put on a new suit of clothes. He has nothing but his feathers to protect him from cold and wet, and as feathers cannot grow out in a minute, he would be left naked, and suffer, if he lost them all at once. So he changes his dress one or two feathers at a time.

Some day a feather will drop from each wing. If you could look, you would see that new ones had started out in the same place, and pushed the old ones off. When the new ones are pretty well grown another pair will fall out.

If all dropped out at once, besides suffering with cold he would not be able to fly, and he could not get his living, and anybody could catch him. But losing only one from each side at a time, he always has enough to fly with.

It is the same way with his tail feathers. He loses them in pairs, one from each side at the same time. 
The soft feathers that cover his body drop out one by one. Thus all the time he is putting on a new suit he still wears part of the old one. In this way he is never left without clothes for a moment.

Most birds put on their new suits just after the young ones are grown up, and before they all start for the South to spend the winter, - that is, with many of our common birds, in August. At that time they are rather shy, and stop singing. If you did not see one now and then, you might think they were all gone.

Sometimes the new fall suit is not at all like the old one. There is the goldfinch, all summer in bright yellow. When he comes out in his new suit in August, it is dull-colored, much like the one his mate wears all the year, and in winter, when goldfinches fly around in little flocks, they look nearly all alike.

In the spring, the male goldfinch comes out again in yellow. He has two suits a year, - a bright yellow one in the spring, and a dull olivegreen for the winter. But his new spring dress is not a full suit. The yellow of the body is all fresh, but the black wings are the same the year round.

Some birds have two, different colored dresses in a year; one they get without changing a 


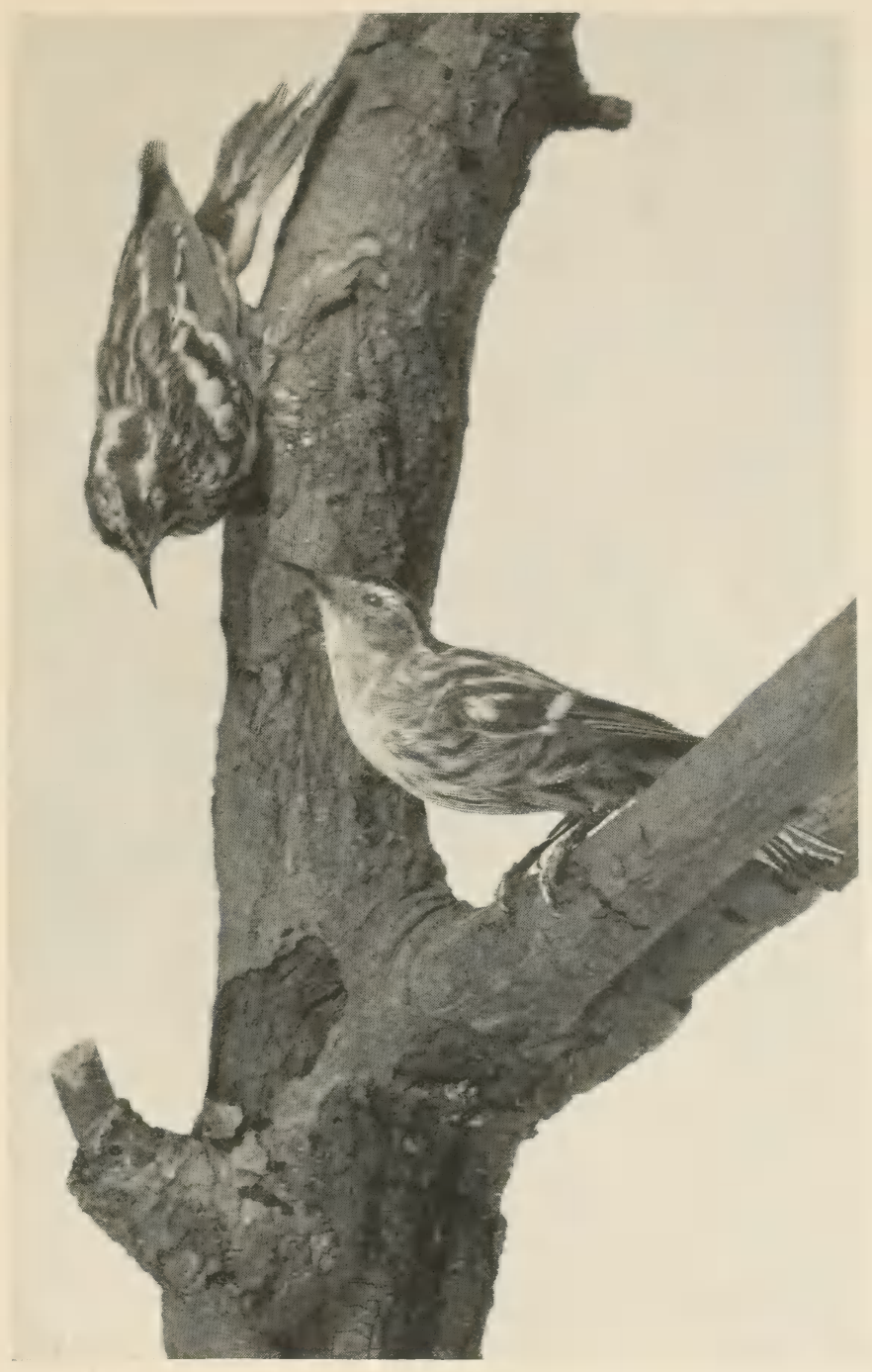

BLACK AND WHITE WARBIERS (MALE AND FEMALE) 

feather. Suppose they have feathers of black, with gray on the outside edges. All winter the gray shows and the birds seem to have gray coats. But in spring the gray edges wear or fall off, and the black shows, and then they look as if they had come out in new black suits. It is as if you should take off a gray overcoat and show a black coat under it.

There is another interesting thing about birds' dress. Some of them look like their mates, the father and mother birds so nearly alike that it is hard, sometimes impossible, to tell them apart. But when that is the case, you will notice that the color is not very gay. If the father wears a bright-colored suit, the mother does not look like him.

For this reason the little mother is not too easily seen when she is on her nest. If the goldfinch mother was as bright as her mate, everybody who came near would see her on the nest, and some animal might take her, and leave the young birds to starve to death. That is probably why mother birds dress in such dull colors.

When birds live on the ground, or very near it, in most cases both of the pair wear the dull colors, so they will not easily be seen. Wrens and sparrows and many others are so. But birds who make their nests in holes, or under ground, 
are often as bright as their mates, because they cannot be seen while sitting, and do not need to wear dull colors.

A curious thing about a bird's color is that the same species, or kind of bird, is darker in one place than another. Where there is much dampness or wet weather, the colors are darker. For instance, a bob-white who lives in Florida, or one who lives in Oregon, will be much darker than his cousin living in New England. 


\section{VIII}

\section{HIS FIRST FLIGHT}

WHEN young birds are in the nest they are not very pretty. But when they are nearly feathered, and sit up on the edge, exercising their wings, and getting ready to fly, they are lovely to look at. Their feathers are more fluffy and fresh than those of the old birds.

At that time they have not learned to be afraid of us, and if we do not frighten them by roughness, loud talking, or quick movements, we can often get near enough to see them well. They will sit up and look at us without fear.

Then some day, all at once, a young bird will begin to flap his wings, and off he will go, fluttering very hard, beating his wings, and trying to reach the next tree.

Sometimes he will reach it, and perch on a twig, and sit quite still a long time, tired with his first flight. Then the parents will come and feed him, and after a while he will fly again. This time he will go farther. 
So he will go on, till in a few days he can fly very well, and follow his parents about, and begin to learn where to get food.

Sometimes when a young bird leaves the nest he does not reach the tree he starts for, but falls to the ground. Then there is trouble among the birds. He is in danger of being picked up by a cat or a boy, or of getting tangled in the grass or weeds.

The poor parents are half wild with fear. They coax him to try again, and they follow him about in the grass, in great distress. I have many times picked up a little bird, and set him on a branch of a tree, or stood guard over him, driving away cats and keeping off people, till he reached a place where he would be safe.

When young birds are out, but cannot yet fly very well, there is much anxiety about them. Then, if any one comes around to disturb them, what can the poor little mother do? Sometimes she makes her young ones hide. Some of the birds who live on the ground will give a certain cry, when in a second every little one will crouch on the ground, or creep under a leaf, and be perfectly still. And their dark colors look so like the earth one can hardly see them.

Then the mother tries to make one look at her by queer antics. She pretends to be hurt, 
and tumbles about as if she could not fly. If it is a man or an animal who has frightened her, he will usually think he can easily catch her; so he will forget about the young ones, and follow her as she goes fluttering over the ground. She will go on playing that she is hurt, and moving away, till she leads him far from her brood. Then she will start up and fly away, and he cannot find his way back to where the little ones are still crouching.

Sometimes when a mother is frightened, she will snatch up her young one between her feet, and fly away with it. Sometimes a mother will fight, actually fly into the face of the one she fears. Often, too, other birds come to her aid; birds of many kinds, - catbirds, robins, thrashers, and others, - all come to help her drive away the enemy, for birds are almost always ready to help each other.

I once found a young blue jay who had come to the ground while trying his first flight. I thought I would pick him up and put him on a branch. But the old birds did not know what I meant to do, and perhaps they were afraid I would carry him off.

They flew at me with loud cries to drive me away, and I thought it best to go, for I did not want to make them any more unhappy than they were already. 
I did not go far, because I wanted to see that no one caught the little one. He hopped about in the grass a long time, while his parents flew around him in great distress. Many times he tried to $\mathrm{fly}$, but he could not rise more than two feet from the ground.

At last he seemed to make up his mind to climb a tree, for when he came to one with a rough bark he began to go up. He would fly up a few inches, then hold on with his claws to rest. And so, half flying and half climbing, he went on till he reached the lowest limb. On that he perched and was quiet, glad to rest after his hard work. The old birds were happy, too, and brought food to him, and so I left them. 


\section{IX}

\section{HIS EDUCATION}

THE young bird has to be educated, or trained for his life, just as we do, though not exactly in the same way.

He does not have to know arithmetic and history; and what he needs of geography is only the road to the South, where he spends his winters.

I suppose the first thing he learns is to fly. You have heard, perhaps, that the old birds drive their young out of the nest. But do not believe any such thing, for it is not true. I have seen many little birds leave the nest, and almost every one flew when the parents were away after food.

The parents sometimes try to coax a nestling who is afraid to try his wings, like an oriole I knew of. All the young orioles had flown except this one, and he seemed to be too timid to try. He stood on the edge of the nest, and called and cried, but did not use his wings. 
The father came to see him now and then, and at last he made him fly in this way. He caught a fine, large moth, and brought it to the nest in his beak. The young bird was very hungry, and when he saw the food, he opened his mouth and fluttered his wings, so eager to get it he could hardly wait.

But the parent did not feed him. He let him see the moth, and then, with a loud call, he flew to the next tree. When the little oriole saw the food going away, he forgot he was afraid, and with a cry of horror he sprang after it; and so, before he knew it, he had flown.

After the young bird can fly, he needs to be taught to get his own living, or to find his own food, and also where to sleep. Then he must learn what to be afraid of, and how to protect himself from his enemies.

He needs to know the different calls and cries of his family, and what they all mean. He has to learn to fly in a flock with other birds, and he must learn to sing. No doubt there are many more lessons for him that we do not know about.

If you watch little birds just out of the nest, you may see them being taught the most useful and important lesson, how to find their food.

The robin mother takes her little one to the 
Baltinore Oriole and Nest 



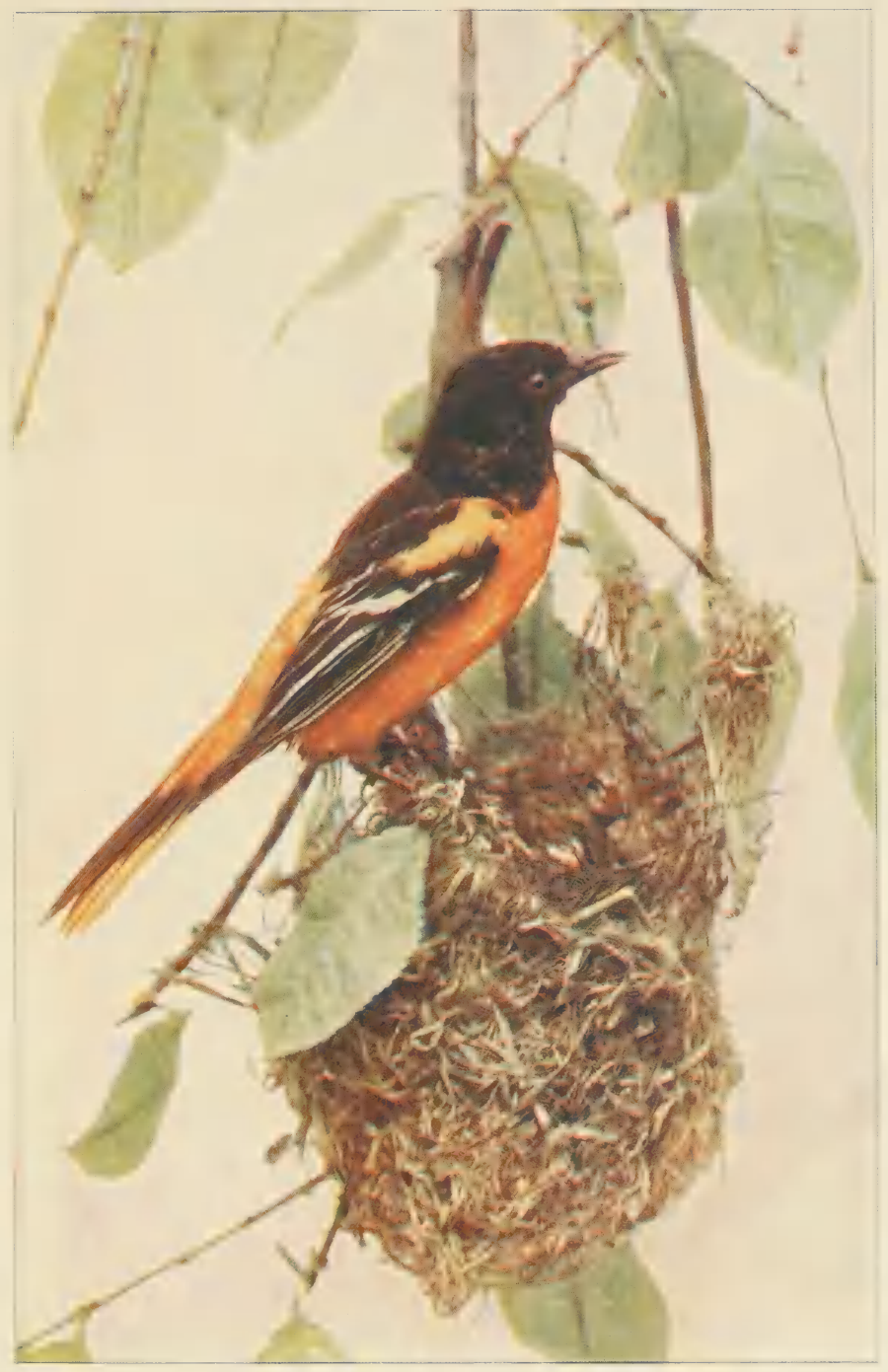



ground, and shows him where the worms live and how to get them. The owl mother finds a mouse creeping about in the grass, and teaches the owlets how to pounce upon it, by doing it herself before them.

The old swallow takes her youngsters into the air, and shows them how to eatch little flies on the wing; while mother phøebe teaches hers to sit still and watch till a fly comes near, and then fly out and eatch it.

If you watch long enough, after a while you may see the old bird, who is training a young one, fly away. She may leave the young one alone on a tree or the ground, and be gone a long time.

Before many minutes the little one will get hungry, and begin to call for food. But by and by, if nobody comes to feed him, he will think to look around for something to eat. Thus he will get his lesson in helping himself.

Once I saw a woodpecker father bring his little one to a fence, close by some raspberry bushes that were full of berries. He fed him two or three berries, to teach him what they were and where they grew, and then quietly slipped away.

When the young bird began to feel hungry he cried out; but nobody came. Then he looked 
over at the raspberries, and reached out and tried to get hold of one. After trying three or four times, and nearly pitching off his perch, he did reach one. Then how proud he was!

The father stayed away an hour or more, and before he came back that young woodpecker had learned to help himself very well; though the minute his father came, he began to flutter his wings and beg to be fed, as if he was half starved.

A lady, who fed the wild birds on her window sill for many years, and watched their ways, says she often saw the old birds teaching their little ones. They showed them where the food was to be found, and, she says, regularly taught them the art of eating.

Then she saw them taught to be afraid of people, not to come too near her. And once she saw an old bird showing a young one how to gather twigs for nest-building. The young one looked on a while, and then tried hard to do it himself, but could not get off a single twig.

Best of all, the same lady heard an old robin giving a music lesson. The teacher would sing a few notes and then stop, while the pupil tried to copy them. He had a weak, babyish sort of voice, and did not succeed very well at first.

I have heard several birds at their music lessons. 


\section{$\mathrm{X}$ \\ SOME OF HIS LESSONS}

IT is very easy to catch the birds teaching their little ones to exercise their wings and to fly together. You will see the young birds sitting quietly on fences or trees, when all at once the parents begin to fly around, with strange loud calls. In a minute every youngster will fly out and join them. Around and around they all go, hard as they can, till their little wings are tired, and then they come down and alight again.

Once I saw a young bird who did not go when his parents called. All the others flew around many times, and I suppose that young one thought he would not be noticed.

But mothers' eyes are sharp, and his mother saw him. So when she came back, she flew right at her naughty son, and knocked him off his perch. The next time she called, he flew with the rest. This was a crow mother.

I have seen a bluebird just out of the nest, 
taught to follow his father in this way. He stood on a small tree, crying for something to eat, when his father came in sight with a beakful of food. He did not feed him, but flew past him, so close that he almost touched him, and alighted on the next tree, a little beyond him.

The little bluebird saw the food, and at once flew after it, perched beside his father, and was fed. Then the old bird left him, and in a few minutes he felt hungry, and began to call again.

I kept close watch, and soon the father came and did the same thing over. He flew past the young one with an insect in plain sight in his beak, and perched on another tree still farther along in the way he wanted the little one to go.

The hungry baby followed, and was fed as before. In this way he was led to a big tree the other side of the yard, where the rest of the family were, and where they all spent the night.

An old robin wanted to teach her young one to bathe. She brought him to a dish of water kept for their use by some people who were fond of birds. The little one stood on the edge and watched his mother go in, and splash and scatter the water. He fluttered his wings, and 


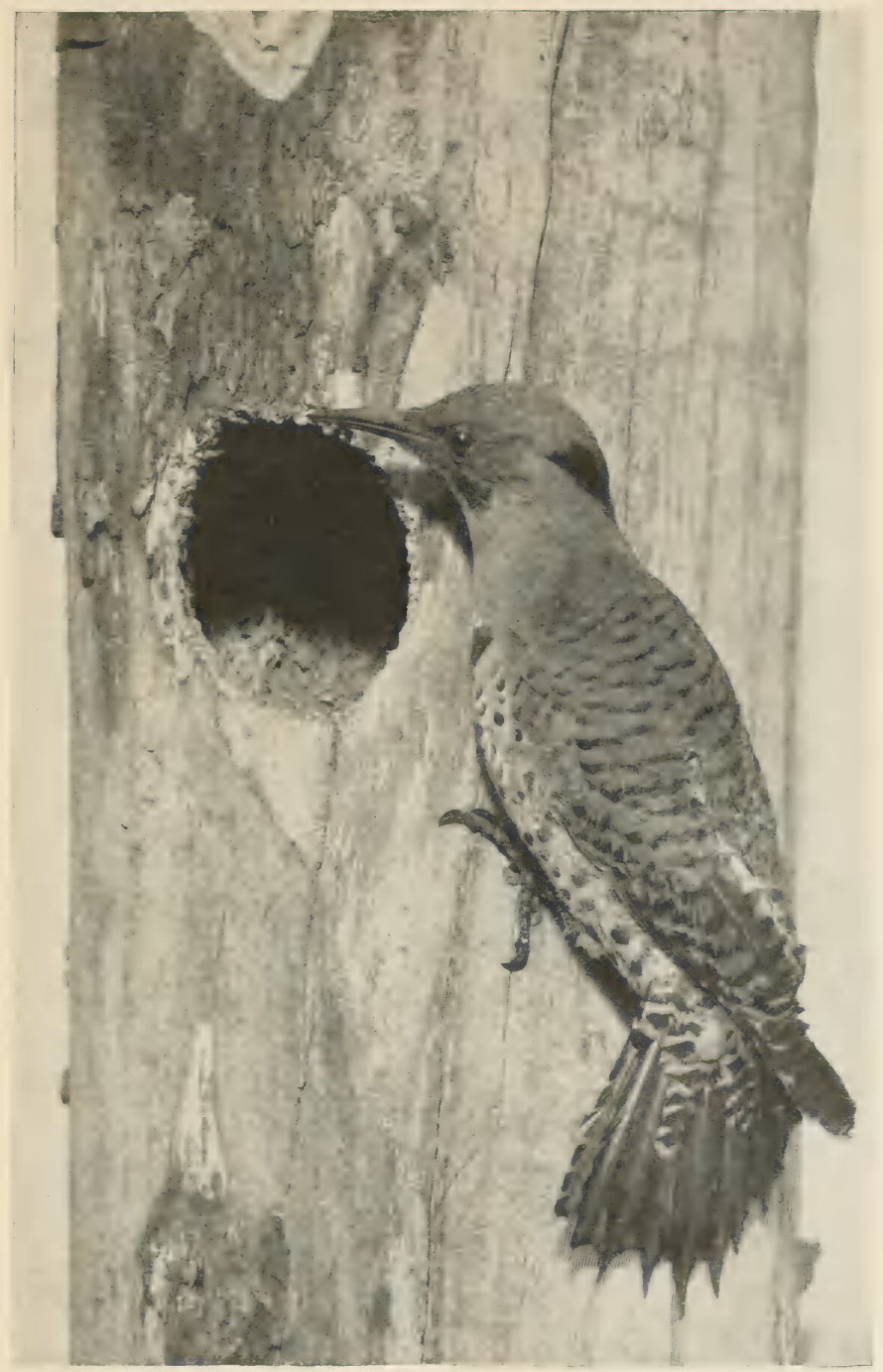

FLICKER 

was eager to try it for himself, but seemed afraid to plunge in.

At last the mother flew away and left him standing there, and in a moment came back with a worm in her mouth. The young robin was hungry, as young birds always are, and when he saw the worm, he began to flutter his wings, and ery for it.

But the mother jumped into the middle of the water dish, and stood there, holding the worm in his sight. The youngster wanted the worm so much that he seemed to forget his fear of the water, and hopped right in beside her. She fed him, and then began to splash about, and he liked it so well that he stayed and took a good bath.

Birds, as these stories show, teach their little ones by coaxing, and not by driving them.

An Englishman, Mr. Lloyd Morgan, once had some ducks and chickens hatched away from their mother, to see how much their parents had to teach them.

He found that these little orphans had to be taught to pick up their food, and to know what is good to eat. He had to show the young ducks how to dive, and teach all of them that water is good to drink.

To see if chickens had to be taught the hen 
language, he put them out by their mother when they were a few days old.

The hen was going about with her brood, all brothers and sisters of Mr. Morgan's chicks, and she was quite ready to adopt the new ones. She clucked and called to them with all her might, but they did not come. They acted as if they did not hear her. When the others ran and crept under her wings to be brooded, the strangers looked on, but did not think of going too.

They did not understand the calls or the ways of their own mother. They had not been taught.

A careful watcher will see the birds teach these things, and many others as interesting. But no one will see anything unless he is quiet, and does not frighten them. 
THE BIRD GROWN UP 



\section{XI}

THE BIRD'S LANGUAGE

WhEN the bird is grown up, there are many other interesting things to know about him,one is, whether he can talk.

It is plain to those who have studied the ways of birds, that they are able to tell things to each other, and many writers have said plainly that birds have a language.

If you notice birds in cages, you will find that when two or more of a kind are in the same room, you will hear little chirps and twitters and other notes, not at all like their song. But if one is alone in a room, he hardly makes a sound except when singing.

Then see a robin out of doors. He is less afraid of us than most birds, and easiest to watch. If something comes up on him suddenly, he gives a sharp note of surprise. If a eat appears, he has another cry which every one can understand, a word of warning to all. If everything is quiet and his mate is near, he will greet her with some low, sweet notes. 
When a partridge mother sees danger, she gives one call, which all her brood know, and at once run and hide. When the hen speaks to her chicks, they know well whether it means to come to her, or to run away.

Of course birds do not use our words. When it is said that the quail says "Bob White," it is meant that his call sounds like those words. To some the notes sound like "more wet." One may call it almost anything, like "all right" or "too hot."

You will read in books about birds, that a certain warbler says "Witches here," or that the white-throated sparrow says "Old Tom Peabody," and other birds say still different things. The writer means that the words remind one of the bird's notes, and so it is useful to know them, because it helps you to know the bird when you hear him.

I have many times seen birds act as if they were talking to each other. You can often see the city sparrows do so.

There is nothing in a bird's ways that we like so well as his singing. And in all the many species of birds in the world, no two sing exactly alike, so far as I can find out. You may always know a bird by his song. A robin does not sing like a thrush or a catbird. And what is 
Bluethind 



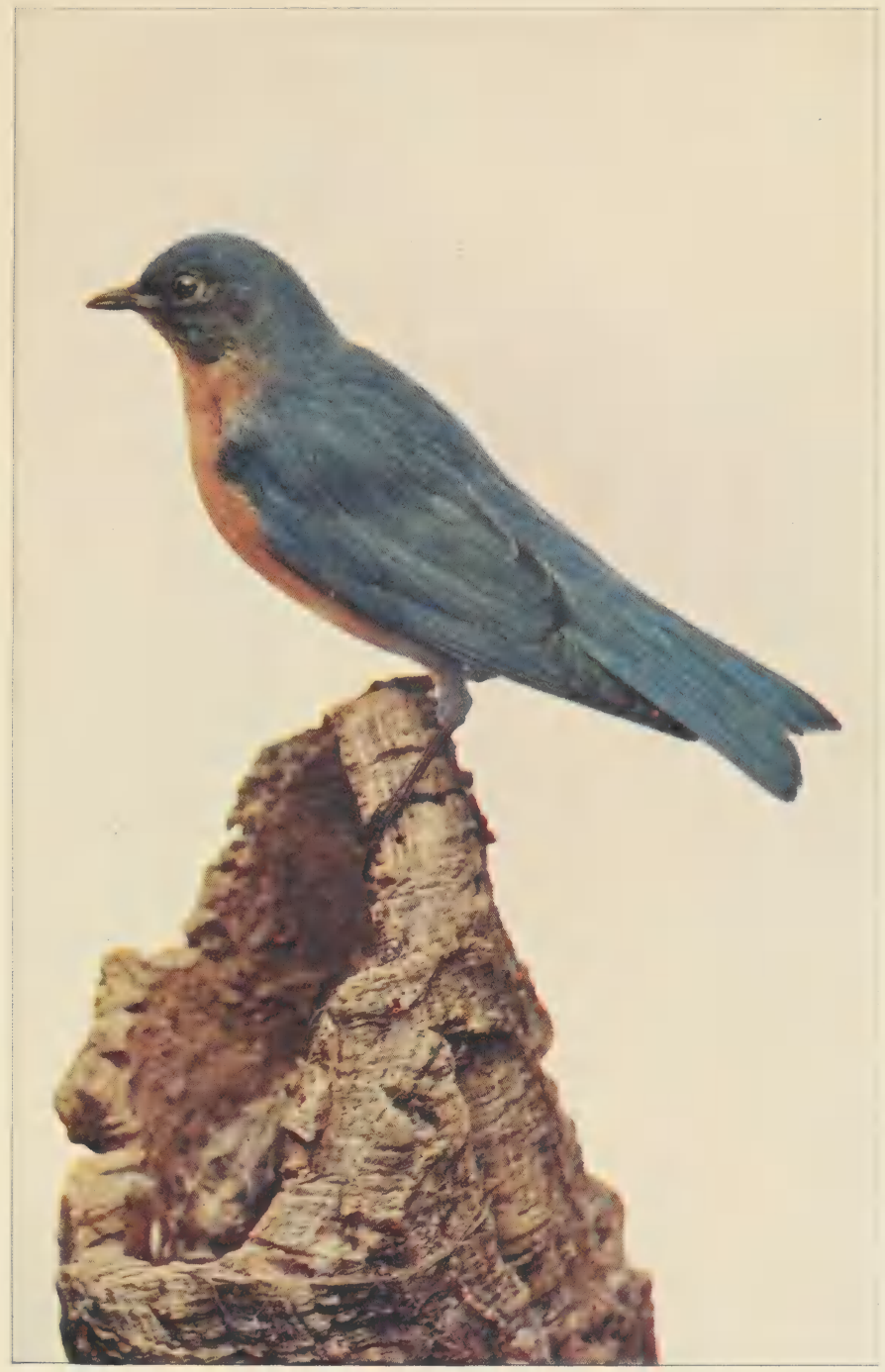



more, not one of the sounds he utters is like those made by any other bird. If you know him well, whatever noise he makes, you will know at once that it is a robin.

But there is something still more curious about it. No robin sings exactly like another robin. When you come to know one bird well, you can tell his song from any other bird's. Of course, all robins sing enough alike for one to know that it is a robin song, but if you listen closely, you will see that it is really different from all others.

Persons who have kept birds in cages have noticed the same thing.

There is still another point to know. One bird does not always sing the same song. I have heard a song sparrow sing five or six different songs, standing all the time in plain sight on a fence. In the same way I have known a meadowlark to make six changes in his few notes.

Besides their own natural songs, many birds like to copy the notes of others. Our mockingbird is very fond of learning new things, and he does not always choose songs either.

He will imitate the noise of filing a saw, or the pop of a cork, as readily as the sweetest song. I have heard one sing the canary's song better than the canary himself. 
Other birds can do the same. A common English sparrow picked up in the streets of a big city, hurt, and not able to fly, was put into a room with a canary.

No doubt the wild bird found his life in a cage rather dull, after having been used to the streets, and he soon began to amuse himself trying to do as the canary did, to sing. In a few weeks he learned the whole song, and he could sing it even better than his roommate, for his voice was full and rich, and not so shrill as the canary's.

Most people think that birds sing all summer. They think so because they have not taken notice. We who are very fond of bird song know it is not so.

Singing begins when the birds first come in the spring. It goes on while the nest is being built, and the mother bird is sitting. The father has little to do at that time, and so he sings. And besides, he seems to be so happy that he cannot help it.

But when little ones begin to call for food, he has to be very busy, and does not have so much time for music. Some birds stop singing as soon as they go to feeding.

But not all do so. Many go on singing till they begin to change their clothes, or to moult, 
as it is called. This happens in August or September, and when it begins, a bird seems to lose his voice.

One of the first to stop singing is the bobolink. He is rarely heard after June is past. The veery is another whose singing days are over early. You may hear his call in the woods, if you know it, but not a song will you hear after the middle of July.

By the time August comes in, almost every bird is silent, except for his calls or "talk." The birds to be heard then are the red-eyed vireo, who seems never to tire, and now and then the indigo-bird, or the wood pewee. And best of all, the dear little song sparrow, who keeps up his cheery songs till the very last.

Then you will know that all the birds are busy putting on their new suits for their long journey. 


\section{XII}

WHAT HE EATS

What the bird eats and where he gets his food are useful things for us to know. It has only lately been found out that birds are the most valuable of helpers to us.

What we cannot eat ourselves, they are happy to live on, and things that make us a great deal of trouble are their daily food.

Some of the things they are fond of are little animals, like mice and ground squirrels, that eat our crops. Others are insects which spoil our fruit and eat up our vegetables, cankerworms and cutworms, and a hundred more.

Besides these, many birds eat the seeds of certain weeds that farmers have to fight all the time.

One reason this helps us so greatly is that birds eat much more for their size than we do. A boy of six or eight years could not possibly eat a whole sheep in one day, but a young bird can easily eat more than his own weight every day. 
They want more than three meals too. They need to eat very often. One catbird will take thirty grasshoppers for his breakfast, and in a few hours he will want thirty more. So he destroys a great many in a day.

Birds begin eating long before we are out of bed, and keep it up till night comes again, or as long as they can see.

You must not think the birds are greedy, as a person would be if he ate every few minutes all day. They are made to do so. It is their business to. destroy insects, small animals, and weeds that trouble us so much, and the more they eat the better for us.

Let us see where they go for food. Each bird has his own place to work.

The catbird watches the fruit-trees, and all day long eats insects that are spoiling our fruit or killing the trees. When the cherries are ripe, we should not forget that he has saved the fruit from insects, and has well earned a share for himself.

If you spent days and weeks picking off insects, would you not think you had earned part of the fruit? "For every cherry he eats" (says a man who has watched him), "he has eaten at least one thousand insects."

The robin eats great numbers of canker- 
worms, which destroy our apples, and cutworms, which kill the corn.

The bluebird sits on the fence keeping sharp watch, and every few minutes flies down and picks up a grasshopper or a cricket, which spoil the grass.

Woodpeckers hunt over the trunks and limbs of trees. They tap on the bark and listen, and if they hear a grub stir inside, they cut a hole in the bark and drag it out. The downy is fond of insects that infest our apple-trees, and he makes many holes in the trunks. But it does not hurt the trees. It is good for them, for it takes away the creatures that were eating them.

Orioles go over the fruit-trees, and pick out tiny insects under the leaves, and when they find great nests on the branches, they tear them open and kill the caterpillars that made them.

Little warblers, such as the pretty summer yellow-bird, help to keep our trees clear, doing most of their work in the tops, where we can hardly see them.

Swallows fly about in the air, catching mosquitoes and tiny flies that trouble us.

Very useful to us are the birds who feed upon dead animals, such as the turkey buzzards, who may be seen any day in our Southern 
States, soaring about high in the air, looking for their food.

What they eat is so very unpleasant to us that we are apt to despise the birds. But we should cherish and feel grateful to them instead. For they are doing us the greatest kindness. In many of the hot countries people could not live, if these most useful birds were killed.

Some persons think buzzards find their food by seeing it, and others are just as sure that they smell it. Perhaps they use both senses. 


\section{XIII}

MORE ABOUT HIS FOOD

Some of the big birds work all the time for us. When you see a hawk sitting very still on a dead limb, what do you suppose he is doing?

A good deal of the time he is looking on the ground for a mouse, or a ground squirrel, or a rat, or some creature that he likes to eat.

When he sees one of them move in the grass, he flies down and pounces upon it. Thus he helps the farmer greatly, for all of these little animals destroy crops.

When it grows dark, hawks stop work and go to sleep. Then the owls, who can see better in the dusk, come out of the holes where they have been half sleeping all day. They hunt the same little creatures, most of all rats and mice, which like best to run about in the night.

Perhaps you have heard that hawks and owls carry off chickens. Many people who keep chickens shoot every hawk and owl they see. But if they knew more about them they would 
not do so. Only two of the common hawks and one owl ${ }^{1}$ disturb chickens. All the others kill thousands of the little animals that give the farmers so much trouble.

Owls have a curious way of eating mice. They swallow them whole, and after a while they throw up a queer-looking little ball made of the bones and fur of the mouse.

You may some time have seen a long-legged heron walking about on the seashore or in the salt marsh. Now and then he would thrust his long, sharp bill into something, and lift up his head and swallow. Or you have noticed a little sandpiper rumning along on the beach or the bank of a river.

The heron was probably eating frogs or fish, and the sandpiper some of the small sea creatures thrown up by the waves. If these were not taken away they would be very bad for us, and perhaps make us sick.

Not less useful to us than these birds are the whole family of finches. The goldfinch in bright yellow coat, the purple finch in red, and the sparrows in plain brown. All of these are fond of seeds as well as insects, and most of all they like the seeds of some weeds that are hard to get rid of.

${ }^{1}$ Cooper's and sharp-shinned hawks, and great horned or hoot owl. 
The goldfinch is called the thistle-bird, because he likes best the seeds of thistles, though he eats the beggar's tick too.

The chipping sparrow, the little red-headed bird who comes about our doors, eats the seeds of fox-tail and crab grasses, that spoil our lawns.

The white-throated sparrow, a large and very pretty bird, eats the seeds of smartweed and ragweed. Other finches like bittersweet, sorrel, and amaranth, all of which we are glad to have them eat.

The seed-eating birds can find their food in winter, even when snow covers the ground, because the dead weeds hold on to their seeds, and the snow is not often deep enough to cover them.

Some birds gather their food in the fall, and hide it away where they can find it in winter. Blue jays collect acorns and beech-nuts, and store them in a hole in a tree, or some other safe place, to eat when food is scarce. A woodpecker who lives in the West picks holes in the bark of a tree, and puts an acorn into each one.

The oddest store I know of was made by a woodpecker. He found a long crack in a post, and stuffed it full of live grasshoppers. He did not like dead grasshoppers. He wedged them into the crack so tightly that they could not get 


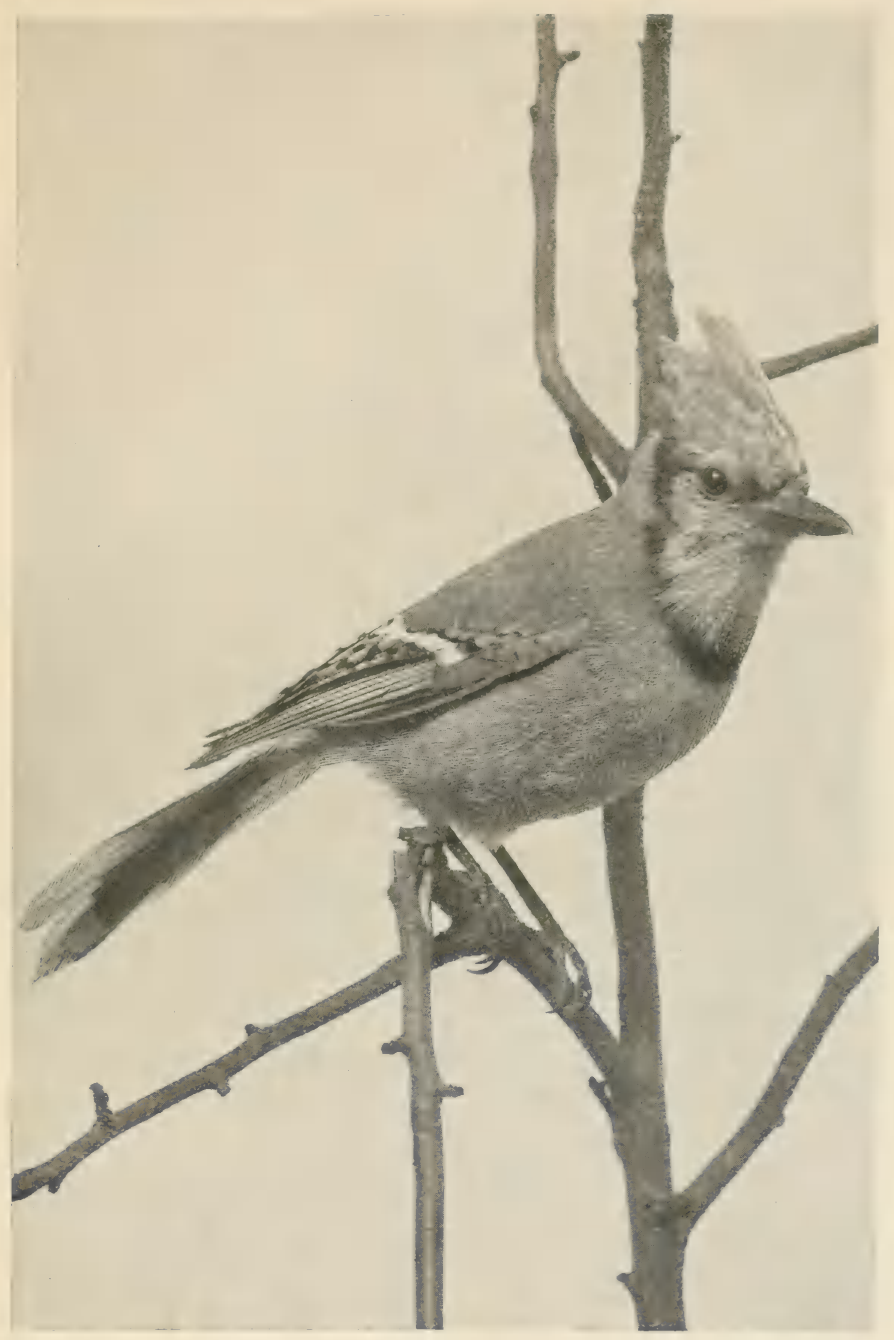

BLLE JAY 

out, and I do not know that they wanted to. When grasshoppers were scarce in the fields, he came day after day to his queer storehouse, till he had eaten every one.

One of the woodpecker family who lives in Mexico stores nuts and acorns in the stems of plants. These stems are hollow and made in joints like bamboo. The bird cuts a hole at the upper end of a joint, and stuffs it full. When he wants his nuts, he cuts a hole at the lower end of the joint and pulls them out.

I once had a tame blue jay, who was fond of saving what he could not eat, and putting it safely away. The place he seemed to think most secure was somewhere about me, and he would come slyly around me as I sat at work, and try to hide his treasure about my clothes.

When it was a dried currant or bit of bread, I did not care; but when he came on to my shoulder, and tried to tuck a dead meal worm into my hair or between my lips, or a piece of raw beef under a ruffle or in my ear, I had to decline to be used as a storehouse, much to his grief.

He liked to put away other things as well as food. Matches he seemed to think were made for him to hide. His chosen place for them was between the breadths of matting on the floor. 
Once he found a parlor match, hunted up a good opening, and put it in. Then he went on, as he always did, to hammer it down so tightly that it would stay. One of the blows of his hard beak struck the lighting end of the match, and it went off with a sharp crack. The noise and the flame which burst out made the bird jump three feet, and scared him nearly out of his senses.

After that I took care to keep the matches out of the way of a bird so fond of hiding things. 


\section{XIV}

WHERE HE SLEEPS

Most birds sleep on their feet.

You know how a canary goes to sleep, all puffed out like a ball, with his head buried in the feathers of his shoulder. He may stick his bill over behind the top of the wing, but he never "puts his head under his wing," as you have heard.

Sometimes he stands straight up on one leg, with the other drawn up out of sight in his feathers, but more often he sits down on the perch, still resting on his feet. Most wild birds of the perching kind sleep in the same way.

It is only lately that we have begun to find out where birds sleep, because it is dark when they go to bed, and they get up before it is light enough for us to see them.

The only way to catch them in bed is to go out in the evening, and start them up after they have gone to sleep. And this is not very kind to the poor little birds. Some men who are try- 
ing to learn about the habits of birds have tried this way, and so have found out some of their sleeping-places.

One thing they have learned is that the nest is not often used for a bed, except for the mother, while she is sitting and keeping her little ones warm.

Robins and orioles, and others, creep into the thick branches of an evergreen tree, close up to the trunk. Some crawl under the edge of a haystack, others into thick vines or thorny bushes. All these are meant for hiding-places, so that beasts which prowl about at night, and like to eat birds, will not find them.

Tree sparrows like to sleep in holes in the ground like little caves. The men who found these cosy little bedrooms think they are places dug out by field mice, and other small animals, for their own use. And when they are left, the birds are glad to take them.

When the weather is cold, some birds sleep under the snow. You may think that would not be very warm, and it is not so warm as a bed in the house with plenty of blankets. But it is much warmer than a perch in a tree, with nothing but leaves to keep off the wind.

While the snow is falling, some birds find it as good as blankets for their use. Grouse, who 
live on the ground, dive into a snow-bank, and snuggle down quietly, while the snow falls and covers them all over, and keeps the cold wind off. Air comes through the snow, so they do not smother.

Some birds creep into a pile of brush that is covered with snow, and find under the twigs little places like tents, where the snow has been kept out by the twigs, and they sleep there, away from the wind and storm outside.

Water birds find the best sleeping-places on the water, where they float all night like tiny boats. Some of them leave one foot hanging down and paddling a little, while they sleep, to keep from being washed to the shore.

Bob-white and his family sleep in a close circle on the ground, all with their heads turned outward, so that they can see or hear an enemy, whichever way he comes.

Hawks and eagles are said to sleep standing, never sitting on the feet like a canary. Some ducks and geese do even more: they sleep standing on one foot. Woodpeckers and chimney swifts hang themselves up by their claws, using their stiff tail for a brace, as if it were a third leg.

Some birds, like the crows, sleep in great flocks. They agree upon a piece of woods, and 
all the crows for miles around come there every night. Sometimes thousands sleep in this one bedroom, called a crow roost. Robins do the same, after the young are big enough to fly so far.

Audubon, who has told us so much about birds, once found a hollow tree which was the sleeping-room of chimney swifts. The noise they made going out in the morning was like the roar of a great mill-wheel.

He wanted to see the birds asleep. So in the daytime, when they were away, he had a piece cut out at the foot of the tree, big enough for him to go in, and the piece put back, so the birds would not notice it.

At night, after the swifts were abed, he took a dark lantern and went in. He turned the light upon them little by little, so as not to startle them. Then he saw the whole inside of the tree full of birds. They were hanging by their claws, side by side, as thick as they could hang. He thought there were as many as twelve thousand in that one bedroom. 


\section{XV}

\section{HIS TRAVELS}

Most of our birds take two long journeys every year, one in the fall to the south, and the other in the spring back to the north. These journeys are called "migrations."

The birds do not go all at once, but in many cases those of a kind who live near each other collect in a flock and travel together. Each species or kind has its own time to go.

It might be thought that it is because of the cold that so many birds move to a warmer climate. But it is not so; they are very well dressed to endure cold. Their feather suits are so warm that some of our smallest and weakest birds are able to stay with us, like the chickadee and the golden-crowned kinglet. It is simply because they cannot get food in winter, that they have to go.

The fall travel begins soon after the first of July. The bobolink is one of the first to leave us, though he does not start at once on his long 
journey. By that time his little folk are full grown, and can take care of themselves, and he is getting on his winter suit, or moulting.

Then some morning all the bobolinks in the country are turned out of their homes in the meadows, by men and horses and mowing-machines, for at that time the long grass is ready to eut.

Then he begins to think about the wild rice which is getting just right to eat. Besides, he likes to take his long journey to South America in an easy way, stopping here and there as he goes. So some morning we miss his cheerful call, and if we go to the meadow we shall not be able to see a single bobolink.

There, too, are the swallows, who eat only small flying insects. As the weather grows cooler, these tiny flies are no longer to be found. So the swallows begin to flock, as it is called. For a few days they will be seen on fences and telegraph wires, chattering and making a great noise, and then some morning they will all be gone.

They spend some time in marshes, and other lonely places, before they at last set out for the south.

As the days grow shorter and cooler, the warblers go. These are the bright-colored little 


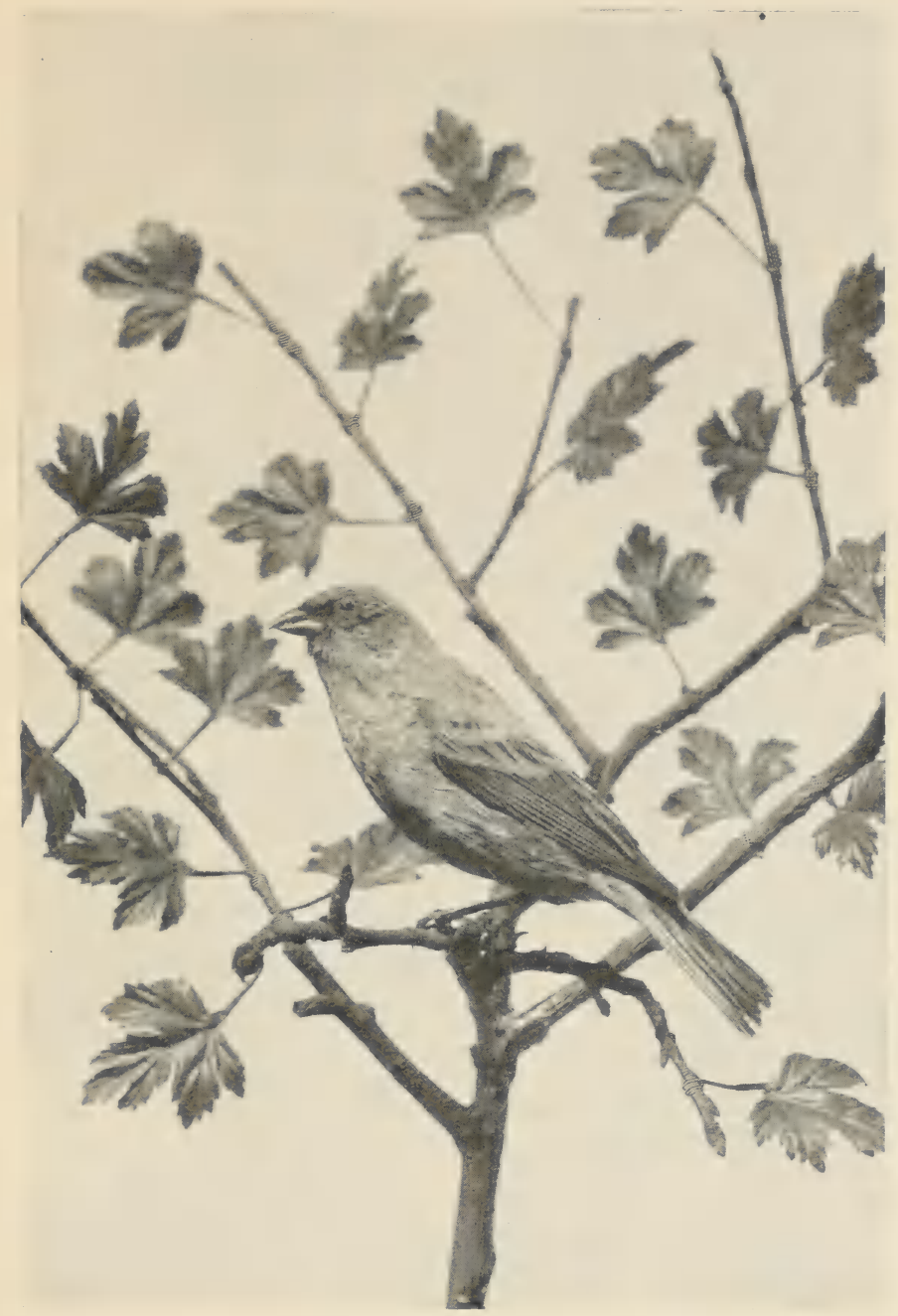

INDIGO-BIKD 

fellows, who live mostly in the tops of trees. Then the orioles and the thrushes and the cuckoos, and most birds who live on insects.

By the time that November comes in, few of them will be left. Birds who can live on seeds and winter berries, such as cedar-berries and partridge-berries, and others, often stay with us, - bluebirds, finches, and sometimes robins.

Many birds take their journey by night. Think of it! Tiny creatures, that all summer go to bed at dark, start off some night, when it seems as if they ought to be asleep, and fly all night in the dark.

When it grows light, they stop in some place where they can feed and rest. And the next night, or two or three nights later, they go on again. So they do till they reach their winter home, hundreds or thousands of miles away.

These night flyers are the timid birds, and those who live in the woods, and do not like to be seen, - thrushes, wrens, vireos, and others. Birds with strong wings, who are used to flying hours every day, and bolder birds, who do not mind being seen, take their journey by daylight.

Most of them stop now and then, a day or two at a time, to feed and rest. They fly very high, and faster than our railroad trains can go. 
In the spring the birds take their second long journey, back to their last year's home.

How they know their way on these journeys, men have been for many years trying to find out. They have found that birds travel on regular roads, or routes, that follow the rivers and the shore of the ocean. They can see much better than we can, and even in the night they can see water.

One such road, or highway, is over the harbor of New York. When the statue of Liberty was set up on an island in the harbor a few years ago, it was put in the birds' path.

Usually they fly too high to mind it; but when there is a rain or fog they come much lower, and, sad to say, many of them fly against it and are killed.

We often see strange birds in our city streets and parks, while they are passing through on their migrations, for they sometimes spend several days with us.

A sparrow, who was hurt and unable to fly, was picked up one fall and kept in a house all winter. He was not caged, and he chose for his headquarters and sleeping-place a vase that stood on a shelf.

He went with the family to the table, and made himself very much at home there. He 
picked out what he wanted to eat and drink, and scolded well if he did not have it.

The thing he liked best was butter, and when he was ready to wipe his bill after eating, as birds do, he found the coat-sleeve of the master soft and nice for the purpose. This pleased the bird better than it did the owner of the sleeve, but he tried in vain to keep the saucy fellow off. If he forgot for an instant to watch the bird, he would dash up, wipe off the butter, and fly away out of the reach of everybody.

In the spring the sparrow left the family, and lived out of doors. But, with the first cold weather of fall, he came back, went to his old vase, and settled himself for the winter again. This he did for several years. 


\section{VI}

HIS WINTER HOME

Nearly every bird has two homes, one for winter and one for summer.

We can see why birds leave us and go to a warmer and better place for the winter; but why they do not stay in that country where there is always plenty of food, but choose to come back in the spring to their old home, we do not know.

It may be because they want more room to build nests, and bring up their little ones. Or it may be that they want to come back because they love their old home.

Whatever may be the reason, it is well for us that they do so, for if we had no more birds in the summer than we have in the winter, we should suffer very much from insects. We could not raise fruit, or vegetables, or grain, for insects would eat it all. That is one reason we are so glad that birds come back to us in the spring. 
Though so many birds leave us in the fall, they do not all go. A few come to us who have nested farther north, and some who have been with us all summer stay over winter too. These last are called "permanent residents," that is, they stay all the year round.

In the Middle States of the East - New York, Pennsylvania, New Jersey, and Ohio - there are twenty or twenty-five who stay all the year. There are several hawks and owls and woodpeckers, the crow, bob-white, the blue jay, and the meadowlark.

Of the little ones, the goldfinch, in his sober winter coat, his cousin the purple finch, the song sparrow, and the nuthatch and chickadee.

Besides these "permanent residents," there are ten or twelve who come from the north. The funny little saw-whet owl is one, and the snowflake, who loves to frolic in the snow, is another.

Many of our summer birds stay in the Southern States all winter. Those who can eat seeds and winter berries - for instance, robins and bluebirds, catbirds and sparrows - need not go very far south; and some of them even stay in the State of New York.

Most of our birds who do not eat berries, but must have insects, go farther, some to Florida 
or the West Indies, others to Central America, and a few even into South America, - except the woodpecker, who gets his insects under the bark of trees.

The summer birds of the Western States nearly all go to Mexico for the winter.

The little birds who stay with us are only those who can eat seeds, as I said, or the eggs and insects to be found in the crevices of the bark on trees. These birds do a great deal of good, for each one destroys thousands of insects before they have come out of the egg. One small chickadee will eat several hundred insect eggs in a day.

These little fellows can almost always find their food, for the snow seldom covers the trunks of the trees; but now and then in the winter we have an ice storm; then the trunks and branches are buried under ice, so that the birds suffer, and perhaps will starve to death.

In such a time it will be kind of you who live in the country to put out food for them. You can give them any table scraps of meat or vegetables, or bread, chopped fine for their tiny mouths, with corn or grain for bigger birds.

What they all like best to eat is suet, - which the butcher will give you, - chopped fine, or, better still, nailed or tied to a branch or a fence, 
so that they can pick off morsels for themselves. This will make them all very happy; but you must see that the English sparrow does not drive them away, or eat it all himself.

Some persons who live in the country or small towns spread a table every day through the winter for the birds. Many come for food, and they have great pleasure in watching them and studying their ways.

One lady I know who is an invalid, and her greatest happiness in the long cold months, when she cannot go out, is to set her breakfast-table, and watch the guests who come to it.

She lives in the southern part of Ohio, and she has all winter cardinal grosbeaks, or redbirds as she calls them, blue jays, tufted titmice, and others. The cardinals are fine singers, and they sing to her every month in the year. 


\section{VII}

\section{HIS FAMILY AND FRIENDS}

Many people think that as soon as the young birls of a nest are full grown, and know how to take care of themselves, the family separate, and have no more to do with each other. Some have even said that the old birds push the little ones out of the nest to get rid of them.

All this is a great mistake, and any one who has watched them carefully will say so.

In many cases, when the brood is grown and all have left the nest, the whole family keep together. One who has eyes sharp to see will find everywhere little groups of parents with their young. If the old birds rear more than one brood in a summer, the young ones of the first nest keep together.

I have often seen little parties of young bluebirds or sparrows going about after food on the grass, or on the newly cut hay. Now and then one of the parents would come around as if to see that all was well, and then leave them alone 
again. When the second brood is ready to go out, the whole family often unite in a small flock. In some cases, where they could be watched, they have been known to stay so all winter. All through July and August, in the New England and Middle States, one may see these pretty little family groups.

Some birds who live and nest by themselves, each pair in its own tree, or bush, or field, come together in larger parties after the young are grown, in a social way. A few do this only at night, in what are called roosts, which I spoke of in a former chapter.

Other birds, when nestlings are out, unite in flocks, and stay so all the time, or through the winter. Our pretty little goldfinch does this.

Most of the birds we see about our homes like to have a tree or bush to themselves for their nest. But there are many birds that live close together all the time. Some, you may say, in small villages, - swallows, for instance. We generally see several swallows flying about together. They make their nests near each other. The barn swallow chooses the beams inside the barn, and there are often three or four or more nests in the same barn.

The eave swallows put their mud cottages in a row, under the eaves outside the barn. One 
would think they needed to have numbers on their doors, to know which was their own.

There, too, are the common crow blackbirds. They come in the spring in crowds, and when it is time to make nests, they find some grove or clump of trees that suits them, and all of them build their nests close together. Often there are two or three on one tree, like a bird city. There they live and rear their little ones, and it is said they never quarrel.

Then there are the birds who get their food from the sea, such as penguins. These birds live in big cities, of many thousand nests. They go to an island where no people live, and build on the ground, or on rocks, or anywhere.

Sometimes they are so near together one can hardly walk without stepping on them. How each mother can tell her own, it is hard to see. They live very happily together, and if a mother is killed, so that her little ones are left orphans, one of the neighbors will adopt them all, and feed and bring them up with her own.

Some of these birds do not even take the trouble to make a nest. They put the eggs anywhere on the sand or earth.

Some one, Mr. Brehm, I think, tells a pretty story about a certain kind of duck who rears two broods every season. After the ducklings of the 
first brood have learned to take care of themselves, they go about together, getting their food and sailing on the water in a little party, while their parents are hatching the second brood. But when the younger ones are big enough, they are led to the water, and at once their elder brothers and sisters join them. They all swim around together, the youngest in the middle of the group, where they are protected and fed by the elder brood as well as by the parents, a lovely and united little family. 


\section{VIII}

HIS KINDNESS TO OTHERS

Birds are helpful to each other when in trouble. If a robin is in distress, other robins will come to see what is the matter, and to help if they can. And not only robins, but catbirds, and orioles, and chickadees, and others, will come, too.

Sometimes when a person tries to rob a nest, all the birds near will come in a crowd, to drive away the thief. They will cry and scream at him, and sometimes fly at his face, and try to peck his eyes.

Birds are so little they cannot fight a man, but if they can peck at his face, they can hurt him, and if they really get at his eyes, they can put them out. We cannot blame the birds for trying to protect themselves and their young, and it is well for boys to be careful how they disturb a nest.

One way it has been found out that birds help each other is that when a man wants to know 
Sourer Fineger 



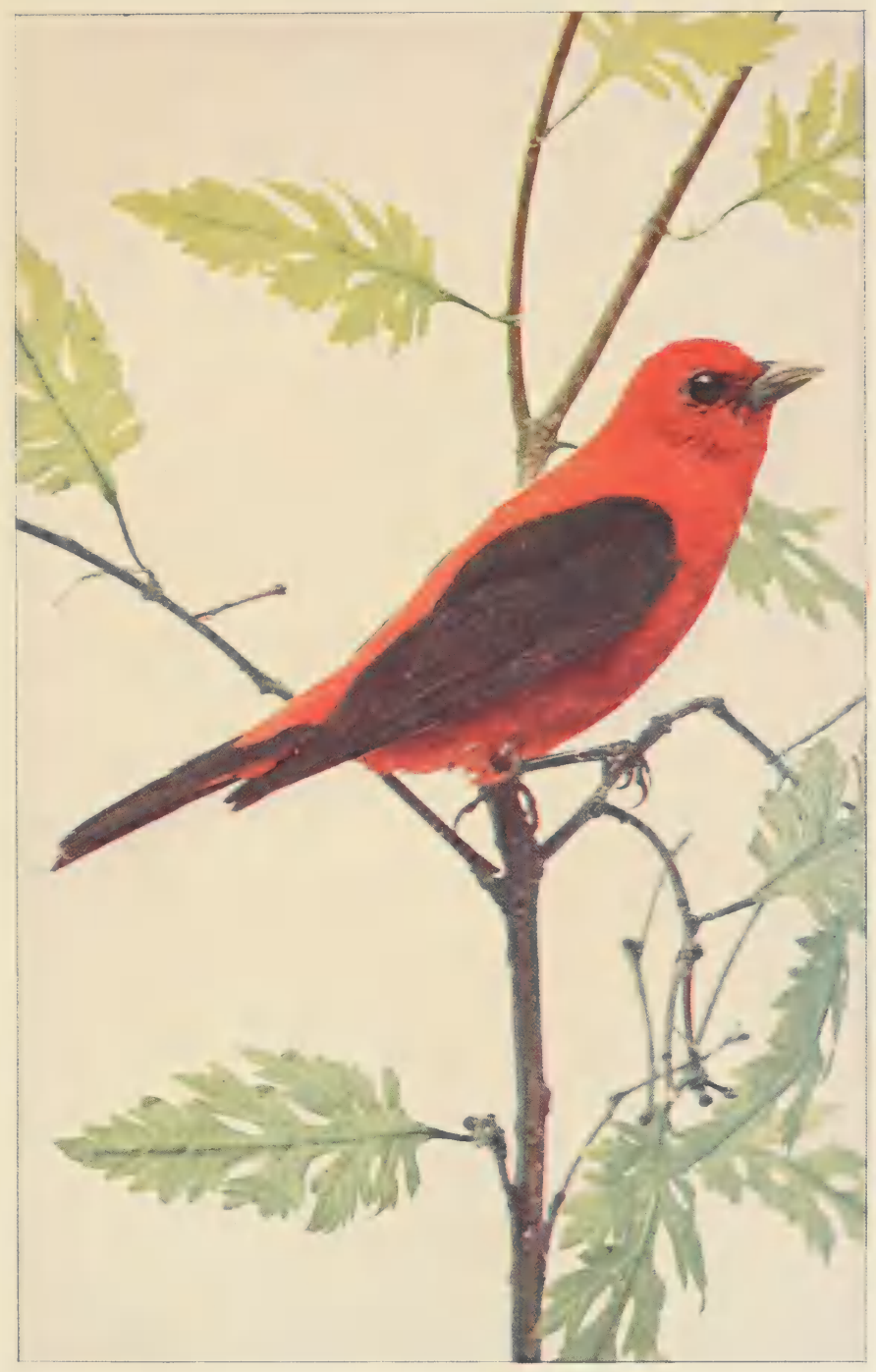



what birds live in a place, he can bring them all around him by making a sound like a young bird in distress. All who hear it will come to see what is the matter.

Let me tell you a story of some young swallows. They were able to fly a little, and were sitting together on a roof, when a lady who was watching them noticed that one of them seemed to be weak, and not able to stand up.

When the parents came with food, the others stood up and opened their mouths, and so were fed, but this little one hardly ever got a morsel.

If birds had no love for each other, as many people think, these strong little ones would not have cared if their brother did starve; but what did the lady see? She says that two of the strong young swallows came close up to their weak brother, one on each side. They put their beaks under his breast and lifted him up on to his legs, and then crowded so close against him that their little bodies propped him up, and held him there; so that he had his chance of being fed as well as they.

Many times birds have been seen who were blind or old, or who had a wing or a leg broken, or were in some way hurt so that they could not take care of themselves, and they were being waited upon by other birds, fed, and led to the water to drink and bathe. 
Birds have been found caught in the lining of a nest, so that they were held there and could not go for food. They had been there for weeks, and would have starved to death if they had not been fed. Yet they were so well taken care of by other birds that they were strong and able to fly.

In one case, where the nest was in a tree trunk, the hole in the trunk had grown up, so that when big enough to fly, they could not get out, and they had been there for months. Yet when a man cut open the trunk and let them out, they were well and lively, proving that they had been fed by friends outside all that time.

I could tell you many true stories of the kind care of birds for each other, and for baby birds who had lost their parents, or been stolen away from them.

A gentleman in Massachusetts told me that when he was a boy he saw a small flock of chewinks who came about a house where food was put out for birds. They came every day, and he soon saw that one was bigger than the rest, and that he never tried to pick up anything for himself, but all the others fed him.

One day he was cruel enough to throw a stone at the bird who was so well taken care of, and when he took up his victim, he found that the 
upper and lower parts of his bill were crossed, so that he could not pick up anything from the ground, where chewinks find their food. $\mathrm{He}$ had been born thus deformed, and if he had not been fed every day by his friends he must have starved to death. Yet so well had he been cared for that he was better grown than any of the party. 


\section{XIX}

\section{HIS AFFECTIONS}

I AM sure I need not say that father and mother birds love their little ones.

So much does the mother love her nestlings that she is often willing to die for them. Orioles and chickadees will let themselves be caught in the hand of one who has taken their young, rather than desert them.

Some birds live in our chimneys, generally in a flue that is not in use, and are called chimney swifts. If a chimney takes fire the mother swift tries hard to get her little ones out, but if they cannot fly, she has been seen to fly into the fire herself, and die with them.

Robins have been found frozen to death on their nest. They could easily have saved themselves, but they would not leave their young ones to perish. A ground bird has been known to sit on her nest during a freezing storm, till she died, rather than go and leave her little ones to suffer.

Once when a young cedar-bird was caught 
and carried off, the father followed it for miles, crying and showing so much distress that the man who had stolen it was sorry for him, and let the little one go.

Every one who has watched them knows that birds love their mates. A man once shot a sea bird, when her mate came about him, crying and showing his grief as well as if he could speak.

I could easily fill a book with stories to prove that birds are loving to their mates and young. And all of them true.

It does not seem strange that birds are fond of their own, but they love others also. And not only other birds, but even animals like cats, dogs, and horses sometimes.

I once had an English goldfinch in the house. He was a little fellow, not so big as a canary, and he was very fond of another bird in the room. This was a scarlet tanager, who was much larger than himself.

The small bird showed his love for his red friend, just as people show love, by staying close to him, singing to him, and driving away any bird who came too near.

A lady once told me of the love of a pigeon for a cat, which she saw. The cat was fond of lying on the broad window sill. When the 
pigeon saw her there, he would fly down, and alight beside her. Then he would press up close to her, and rub against her fur, as if glad to see her, and the cat seemed to enjoy it as much as the bird.

Often a bird who is tamed loves his human friends. A man had a crow who was very fond of him. He had reared the bird from the nest and never shut him up, but let him fly about wherever he chose.

One day he was out in a sudden rain, and his feathers got wet, so that he could not fly well. Then a boy caught him, and carried him seven miles away. He clipped one wing, so that the crow could not fly, and kept him shut in the house all winter. In the spring, the first time he could get out, the bird started for his old home.

He could not fly, but he walked the seven miles, through mud and wet, and came home so tired that he was almost dead. When his master saw him coming he went to meet him, took him up and petted him, and talked to him.

The poor fellow was so happy it seemed as if he could not live. But he was taken care of, and got well, and lived many years. But never after that would he leave the place, though when his new feathers came in he could fly as well as ever. 


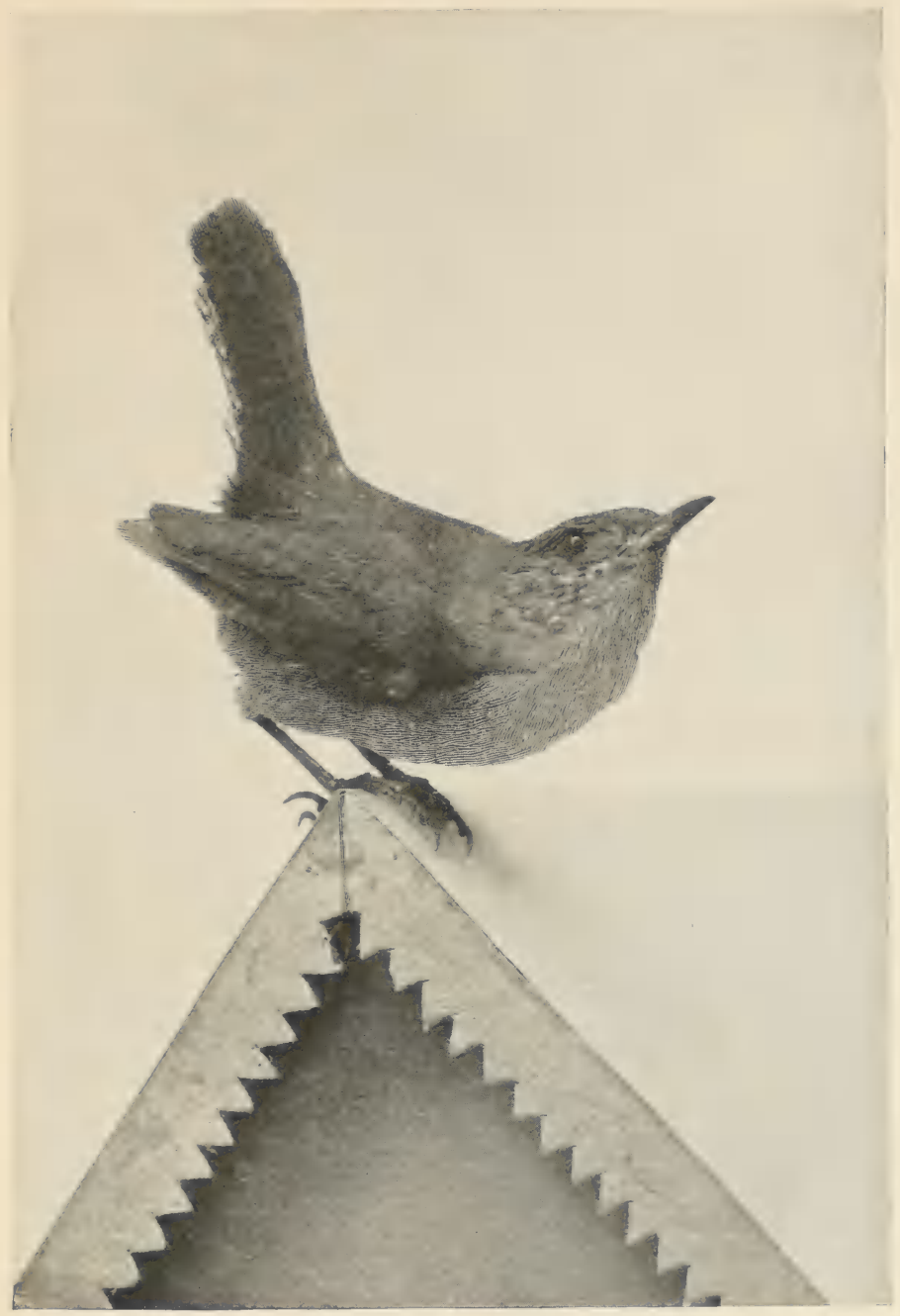

HOUSF WRF.N 

Canary birds often love their mistress. I have heard of one who was so grieved by a harsh word, that in a few minutes he fell off his perch dead.

These true stories show us how tender and loving these little creatures are, and how careful we should be to treat them gently and kindly.

An interesting and true story is told by a clergyman in Ohio. It is a habit of wrens to find a good nesting-place, and then look for a mate to occupy it. One spring a wren chose a nice bird-box on his place, and held it ready for the expected bride. But she did not come, and a pair of English sparrows took a fancy to the same house.

Sparrows expect to get what they want, and are always ready to fight for it, so they gave battle to the wren. But wrens also will fight for their own, and this wren held his house against the enemy for two weeks. Still the mate did not appear, and finally the lonely bird lost heart, and let the sparrows set up housekeeping in his box, though he did not go away.

When the young sparrows were hatched, and feeding began, the wren suddenly became friendly. He hunted up small green worms, probably such as are good for wrenlings, and offered them to the young sparrows. 
Nestlings are never known to refuse anything to eat, and wren food seemed to suit the sparrows, for they soon outgrew the nursery.

All summer this queer thing went on. The sparrows reared three or four broods, and the wren did his full share of the work. And not only of feeding the young, but of repairing and rebuilding the nest for each fresh brood. 


\section{XX}

\section{HIS INTELLIGENCE}

Before people knew very much about the ways of birds, it was thought that they do not have to be taught anything, but that they know everything they need to know, as soon as they are born. That is, they were said to act from instinct alone, and not at all from reason, as we do.

Another notion that people had was that birds of a kind are just alike. That they look exactly like each other, all act in the same way, and all sing the same song.

But since we have begun to study birds more closely, we find these things are not true. We find that birds learn things by being taught, as we do. Also, they find out how to do things themselves, and they are not all alike, as so many machines.

More than this, we see that they do not look nor act exactly like each other. For when we know one robin or one oriole well, we can tell 
him from any other robin or oriole. And, as I said before, no two of a kind sing precisely the same song.

A bird shows his intelligence in many ways. One is by the way he acts when he cannot do as he is used to doing. A robin I know of wished to build a nest, but could not find mud to put into it, for it was a very dry time, and there were no streams near. Now a robin's nest must have mud, and the bird seemed puzzled for a while. But at last she thought of a way to get it.

She went to a bathing-dish that the people of the house kept filled with water for the birds, jumped into it, and got her legs very wet. Then she flew to the road, and tramped around in the dust and dirt.

In a short time her legs had a good coating of mud, which she carefully picked off with her bill, and took to the nest she was building.

This she did a great many times, and the lady who told me of it watched her till she had as much mud as she needed.

A bird often shows sense by the way she repairs a nest that has been thrown out of place. Sometimes she will add a new stay, tying the nest to a stronger limb. One sparrow, whose nest broke loose, put so many stays to the 
branch above that they made a little roof like a tent over it.

Another way a bird shows reason is in seeing the advantage of a new place. A pair of swallows lived far out in the West, hundreds of miles from any house. They had no doubt always nested in a cave, or hole in a tree. But one day they found a house put up. It was a mere shed, to be used as a blacksmith shop, by a party of men who were looking over the country.

At once the birds saw how nice it would be to have a roof over their heads. And although there was a big fire, and the noise of men at work, they built the nest over the anvil, and reared the family in safety.

Woodpeckers have shown that they can learn. Some of them have found an easier way to get food than to dig through the bark of trees for it.

The flicker, or golden-winged woodpecker, has learned that ants and other insects are good to eat, and now he does not think of digging into bark any more.

The red-headed woodpecker has learned to catch flies like a common flycatcher. The yellowbellied, or sapsucker, cuts holes in the trees, and eats the insects that come to feed on the sweet sap that drips from them. 
Woodpeckers have also learned to cut a hole through a board and nest inside a building, instead of drilling a deep hole in the trunk of a tree for a nest.

Birds show intelligence when they draw us away from their young ones, by acting as if they were hurt and not able to fly. I have already spoken about that.

Sometimes when a bird is caught he will lie quiet and pretend to be dead. But all the time he is looking out for a chance to fly away.

A man who watched birds very closely once saw an interesting instance of their intelligence. They were two of the birds who get their food on the seashore by turning over stones and eating the creatures hidden under them. They had found a big dead fish thrown up on the beach and half buried in sand. Under such a fish they were sure they should find food, so they went to work to turn it over. The fish was three and a half feet long, and the birds were about as big as our sandpipers. So it was a hard thing to do.

First they pushed against it with their beaks and breast, but it did not move. Then they went around the other side and scratched away a good deal of sand from under the fish, and went back and tried again to turn it over. Still it was too heavy to stir. 
Again they ran around the other side, scraped away more sand, and tried it once more. They kept up this work for half an hour, but did not succeed in stirring the great fish.

At this time the man, who had hidden himself to watch them, saw another bird coming. The two little workers greeted him with joyful cries, to which he replied in the same tones. Then all three set to work on the heavy fish. They dug more sand out from the lower side, and then pushed against the upper side with all their strength. They lifted it a few inches, but it fell back.

At last, after resting a few minutes, without moving from their places, they worked it in this way. They rested their breasts on the sand, put their beaks under, and lifted. When the fish was raised several inches, they held it with their beaks and pushed their breasts against it, when over it went, down the little pitch they had made.

They could not stop, and they went with it, but at once came back and found enough to pay them for their hard work.

One who really watches birds to see what they are doing will see many actions that show intelligence and reason. 





\section{XXI}

\section{HIS BODY}

DID you ever think how well the bird is made to suit his life? Look at him.

To fit him to move through the air in flying, his shape is the same that men make their boats to move through water. It is sharp in front to cut his way as he goes through, for even the air needs to be cut.

It is narrower toward the back, and as he flies, the feet are drawn up or trail behind, and even the feathers lie backward. All this is so he can go swiftly through the air, and nothing, not even a feather, will hold him back.

To keep his body upright, so that he will not be top-heavy and tip over as he flies, his weight is mostly below the wings.

If we should try to go through the air as fast as a bird goes, we should find it very hard to breathe. But the bird is made for it. When you come to study his anatomy, you will see what a wonderful little creature he is. 
He can $\operatorname{sing}$ while he is working very hard to fly upward. If you will try to sing while running up a hill, you will see how hard it is to do that.

A bird's head is joined to his neck at one place, something like a hinge. Other animals, like dogs and eats, have two hinges, or places of joining. That is why a bird is able to turn his head around so far that he can look down his own back. No other creature can do so.

Because of this, he is able to dress every feather on his body, and to sleep with his head laid back on his shoulder.

Nearly all birds have some of their bones hollow, and air-sacs, or pockets, under the skin. These sacs they can fill with air and make themselves light, so that those who live in the water cannot sink, but float like a cork.

Men who study the way birds are made do not yet know all the uses of the hollow bones and air-sacs. That is one of the things left for you young folk to find out.

Birds who get their food in marshes, or the edge of the water, have long legs for wading. They have also long necks, so they can pick up food from the ground.

Birds who swim have webs between the toes, that turn their feet into paddles. 


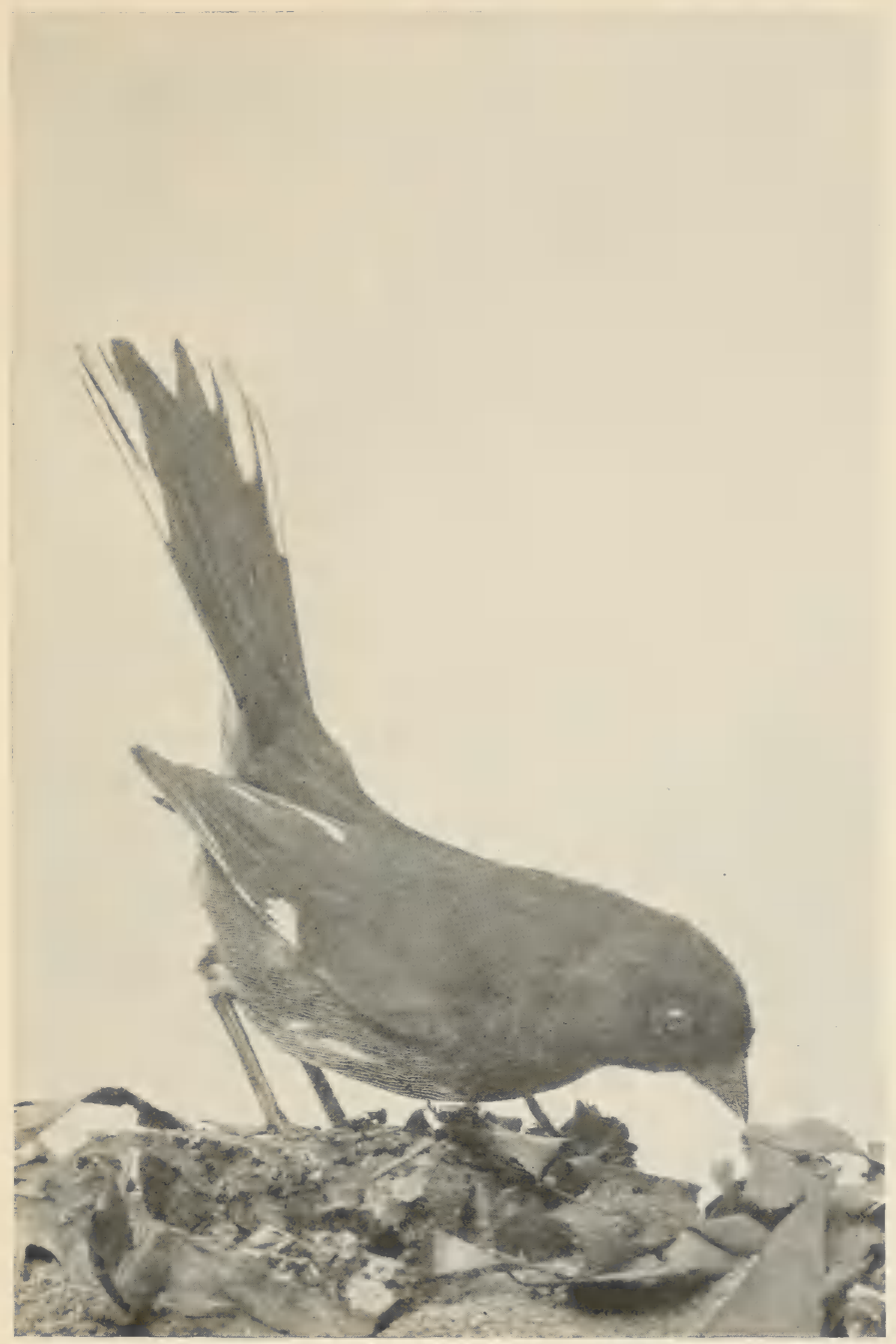

CHEEWINK, OR TOWHEE 

Birds have very large gullets. In many cases they lead into a place called the crop, where food is kept before it goes into the stomach. Sometimes the food is made soft in the crop, and then fed to the young ones, as I told you.

Birds have no teeth, yet they eat hard seeds, like acorns and grains of corn. To break these up, and get them ready for the stomach, they have a gizzard, which is a sort of grinding-mill. And to help in the work of grinding they swallow small stones.

One of the wonderful things about birds is the height at which they can live, and not only live, but fly. A man cannot go higher than twentytwo or twenty-three hundred feet, while moving about or exercising, because the air is so rare he cannot breathe. The highest a man was ever known to go and live, it is said, was less than thirty thousand feet, and that was in a balloon, where he did not move.

But birds go a good deal higher than this, and can fly - which is violent exercise - at that height. It is thought by some that the rarefied air may be the cause of the great speed with which birds fly in that region. But there is still much to be found out about this.

Besides the marvels of flight, birds have other powers almost as strange. Many of them can fly 
under water with perfect ease, and, more than that, they can, when they wish, sink slowly till nothing is left above water but their beaks, to breathe. And they can stay so as long as they choose, keeping still in one spot, without moving.

A cormorant in a zoölogical garden, who wanted to catch some of the swallows skimming over the pond, sank his body till only his head was out, and held himself there perfectly still.

Birds who are hunted, as geese, have been known to save their lives in that way, by sinking their body under water, leaving in sight only the tip of the bill, which is so small it is not readily seen.

To do such things, birds must be able to make their bodies heavy when they choose, as well as light, which we know they are able to do by filling their air-sacs and hollow bones with air.

There are many things still to be found out about the powers of birds. 


\section{XXII \\ HIS BEAK AND TONGUE}

How does a bird get along without a hand? He has to prepare food; to keep his feathers in order; to build the nest; to feed and take care of the young; and sometimes to fight other birds. How can all this be done without a hand?

The beak is the only thing

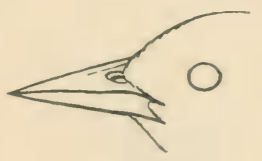

FIG. 1.

Bill of Oriole. most birds have in place of a hand, and it is wonderful to see how many things they can do with it.

Orioles use it as a needle, in making the nest. With it they weave strips of soft bark or strings, back and forth, in and out, to make the firm

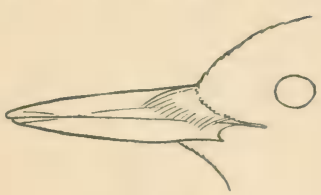

FIG. 2.

Bill of Woodpecker. pocket they hang on the elm-tree (see Fig. 1).

A woodpecker's beak is a chisel or pick, to cut a deep hole in a tree trunk for a nest (Fig. 2). With 
a nuthatch it is a hammer, to crack the nut he has wedged into a crevice in the bark so tightly it cannot slip.

Some birds use the beak to dig in the ground, as the bank swallows, while the barn

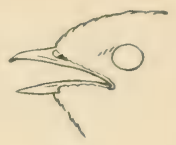

Fig. 3.

Bill of Swallow. swallows make it a trowel, to carry and plaster mud (Fig. 3). All of them use it as a hand to feed themselves, and a brush and comb to dress their feathers.

Birds need to use the beak a good deal, because in most cases it grows like our finger-nails. If they did not keep it worn off, it would grow so long as to trouble them. Sometimes when a bird lives in a cage and does not use his bill, it grows so long that he can hardly pick up his food.

The woodcock's long beak is sensitive, so that he can feel the worms, deep in the mud where they live. Many waders and swimmers have beaks soft like leather.

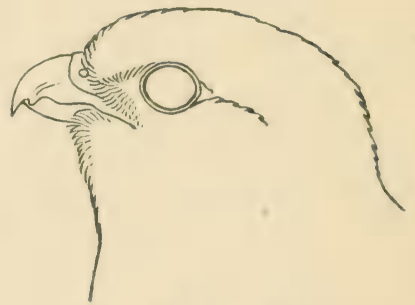

FIG. 4.

Bill of Hawk.

You can tell by the shape of the beak how a bird lives, and what he eats. The strong, hooked 
beak of a hawk shows that he catches live animals to eat (Fig. 4). The long, narrow, sharp bill of a heron shows that he spears his prey, often under water.

The sharp-pointed bill of a warbler is to pick tiny insects and eggs out of blossoms, and from under leaves. The sharp-edged bill of a sparrow (Fig. 5 ) is to break open the hard shells of seeds.

The curious beak of a crossbill (Fig. 6) is to pick seeds out of pine cones.

A duck's wide beak, with a strainer at the edge, is to let water out while keeping food in. A

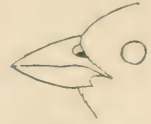

FIG. 5).

Bill of Sparrow.

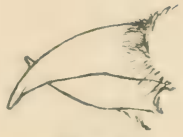

Fig. (i.

Bill of Crossbill. spoon-shaped bill is to scoop up food, and a thin, flat one is to poke into narrow cracks.

Both parts of the beak, which take the place of our jaws, are called mandibles, upper and lower. Both of them can be moved, while we can move only our lower jaw.

Birds' tongues are as curious as their beaks. To all birds they take the place of a finger, as the beak takes the place of a hand, and they differ as much as the beaks from each other.

Insect eggs are very small, and often packed snugly into cracks and corners, and the birds 
who eat them have a brush on the tip of the tongue, which brushes an egg out of its hidingplace very easily.

The nuthatch picks his small grubs out of crevices in bark with the four-tined fork at the end of his tongue.

A hummingbird's tongue can be used as a tube, to draw up the honey of flowers,

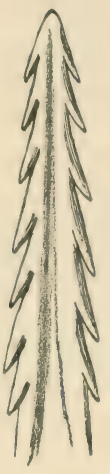

FIG. 7.

Tip of

Tongue of Downy

Woodpecker. or perhaps as a pair of tweezers, to pick out the tiny spiders that live there.

A woodpecker has barbs on his tongue, to spear insects hidden under the bark, as shown by Mr. Lucas (Fig. 7). It is said to be sticky also, to hold small ones, like ants.

The tongues of birds are of many shapes, but each one is fitted to its owner's way of getting a living.

Because the tongue is often horny, and they eat strange things, it is sometimes thought that birds have little sense of taste. But we cannot be sure of this, and we know they all have notions about their food.

Dr. Ward tells a story of some geese, which shows that they do not lack that sense. While sailing upon a river he noticed on the bank some geese, feeding on the rinds of watermelon, 
which they picked out of the garbage dumped there.

The rind, when taken out of the mass, was none too clean, being covered with mud and other dirt. When a goose found a piece to suit him, he took it up, carried it to the edge, and dropped it into the shallow water. Then he stood and watched it till the running stream washed it clean, when he stepped into the water and quickly ate off the part he wanted. 


\section{XXIII}

\section{HIS EYES AND EARS}

Binds' eyes are very different from ours. To begin with, they are round. Then they are placed one on each side of the head, so that they can look two ways at once. Owls are the only birds who have eyes turned forward like ours.

Birds' eyes also are of many colors. Besides our common black, brown, blue, and gray, birds have light and dark green, bright red, pale and deep yellow and orange, even white.

They have, like us, two eyelids. But while we use the upper one to close our eyes, most birds use the lower one. They have also a third eyelid, inside the others, a thin, white sort of skin, that moves across the eye from side to side, and is called the "nictitating membrane."

There are other ways in which birds' eyes differ from ours. The men who try to know exactly how birds are made have found out that birds' eyes make everything look much larger 
Rediturts (finuic on liest) 



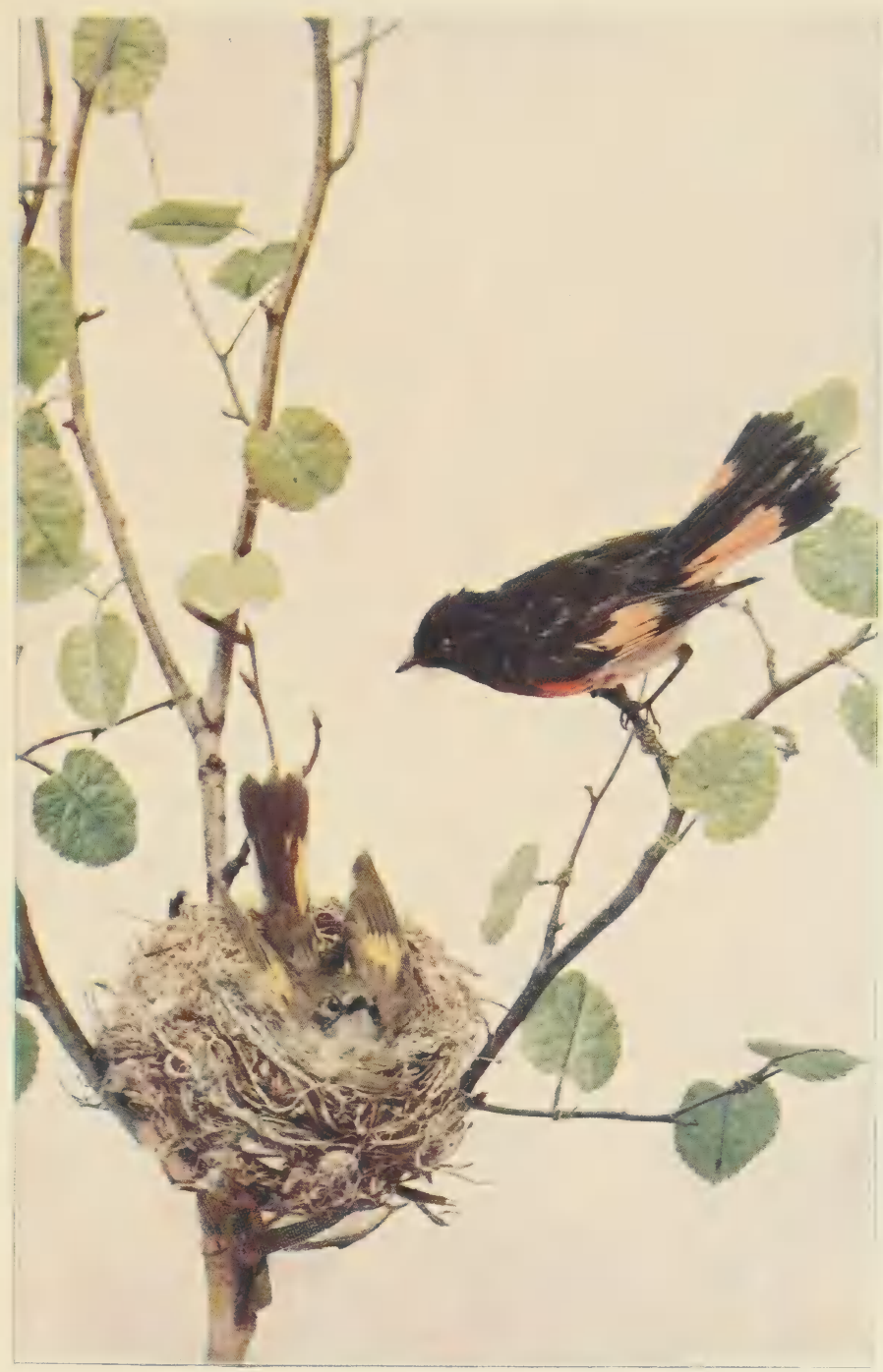



than it is, in other words, they are like magnifying glasses, or microscopes, so that a tiny insect egg, that we can hardly see, looks very big to a warbler.

Stranger still, when a bird is far off, his eyes are like telescopes. That is, when a hawk is soaring about far above the earth, he can see a mouse on the ground as well as if he had a telescope to look through. And the gulls who sail about orer the shore, and follow steamers on sea voyages, can see small fish and tiny bits of bread thrown out by the passengers, even when they are lost to us in the foam made by the vessel.

Mr. Frank Bolles had a pet barred owl, and used to take him out with him. He says that the bird's sight was wonderful, better than bis own aided by a strong glass. Many times the bird would see and watch a hawk so far off that Mr. Bolles with his glass could not see him until he came nearer, and then he looked no bigger than a dot against the sky.

There is a story told of some small birds migrating over the island of Heligoland, suddenly coming down in a flock on to a man's garden, and beginning at once to work among the leaves as if they were feeding.

The owner of the garden knew they did not 
eat leaves, so he shot a few and found them stuffed with small caterpillars. Then he looked at the plants and found many more caterpillars, each in the curled-up end of a leaf. The insects could not be seen, yet the birds, while flying over, no doubt saw the curled leaves and knew they were there.

Such eyes must be of great use in helping birds to find their food, and to avoid their enemies. But think what giants we must look to them! It is no wonder they are afraid of us.

Perhaps even more useful to a bird than his eyes are his ears, though they are so nicely covered up by the feathers that we cannot see them. The tufts of feathers that stand up on some owls' heads, and are called ears, are not ears at all, but merely decorations, like the crests of some birds and the long tail feathers of others.

But because they cannot be seen, we must not think birds have no ears; they have very good ones indeed. They can hear much better than we can.

Every one has seen a robin run over the grass and turn his head one side to listen. It is supposed that he hears the earthworm move under the sod, and if he is watched, he will often be seen to pull the worm from that very spot. 
When a woodpecker taps on a tree trunk and turns his head to listen, it is thought that he hears the grub stir under the bark, for when he begins to cut the bark away, he is pretty sure to find and draw it out.

Birds that are much hunted by men, like ducks and geese, get to be very knowing, and show how wonderful is their hearing. They can tell the difference between a noise made by an animal and that made by a man. A deer or any animal may crash through the bushes, and they pay no attention to it, but if a man makes the least sound they are off in an instant.

A bird's ears are behind the eyes, and a little below them. They are covered by delicate feathers that hide them from sight. When the bird raises these feathers - perhaps to hear better - they look like tiny ear muffs.

Owls have little flaps of skin with which they can shut up their ears when they wish to be quiet. This must be very useful to birds who prefer to sleep during the day, when nearly everybody else is awake and making a noise. Many of us who live in cities would like to be able to close our ears sometimes.

Mr. Bolles tells a story about the sharp hearing of a heron. The bird was on a tree dressing his plumage, and he was hidden in some bushes and could not be seen. 
Mr. Bolles made all sorts of noises to start up the heron and make him fly. First he imitated animal sounds. He quacked, and barked, and mewed, and brayed, and the bird looked interested, but not at all alarmed. Then he whistled and sang, and at last talked plainly, but the bird only looked over his way, as if to see what new sort of beast was hidden there.

No noise that he could make startled the heron in the least, until a twig snapped under his foot, when the bird was off like a shot. That sound he well knew was made by his most feared enemy, a man. 


\section{XXIV}

\section{HIS FEET AND LEGS}

A BIRD always stands on his toes, not on his whole foot, as we do. The long slim part that we call the leg is really the foot, and the joint we see nearly up to the bird's body is the bird's heel. But in this book we will speak of it in the common way, calling the toes the foot, and the part up to the joint the leg.

People all over the world have the same kind of feet and the same number of toes; but with birds it is not so. Most of them have four toes (Fig. 8), but some

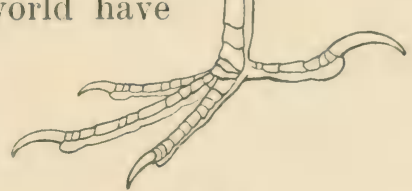
Fir: 8.

Foot of Blackbird.

have only three, and a few have no more than two.

In the use of the feet there is still more variety. There are, as Dr. Coues divides them, three kinds of feet among birds : - 
First, a foot that can be used like a hand to clasp a perch, a "perching foot."

Second, one that is good to use as a foot, but not at all like a hand, called a "scratching foot."

Third, one that is like neither hand nor foot, but a paddle, called a "swimming foot."

The birds who have the first kind, the "perching foot," have usually three toes

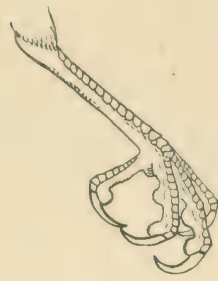

Fig. 9.

Foot of Hawk. turned forward and one turned back. They can grasp a branch or a twig as tightly as if with a hand, as all our common little birds do. And the large birds of prey, such as hawks and owls (Fig. 9), hold in them live mice and squirrels and the other little animals they eat.

Some birds with perching feet have the toes placed another way. Woodpeckers have two turned forward and two turned back, so that they can hold better to a tree trunk (Fig. 10).

A strange thing about the perching toes is the way they are made to hold on, so that the birds can sleep on a

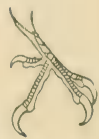

Fig. 10. Foot of Woodpecker. perch, and not fall. Inside the toes are tendons, something like cords, which act like elastic rub- 


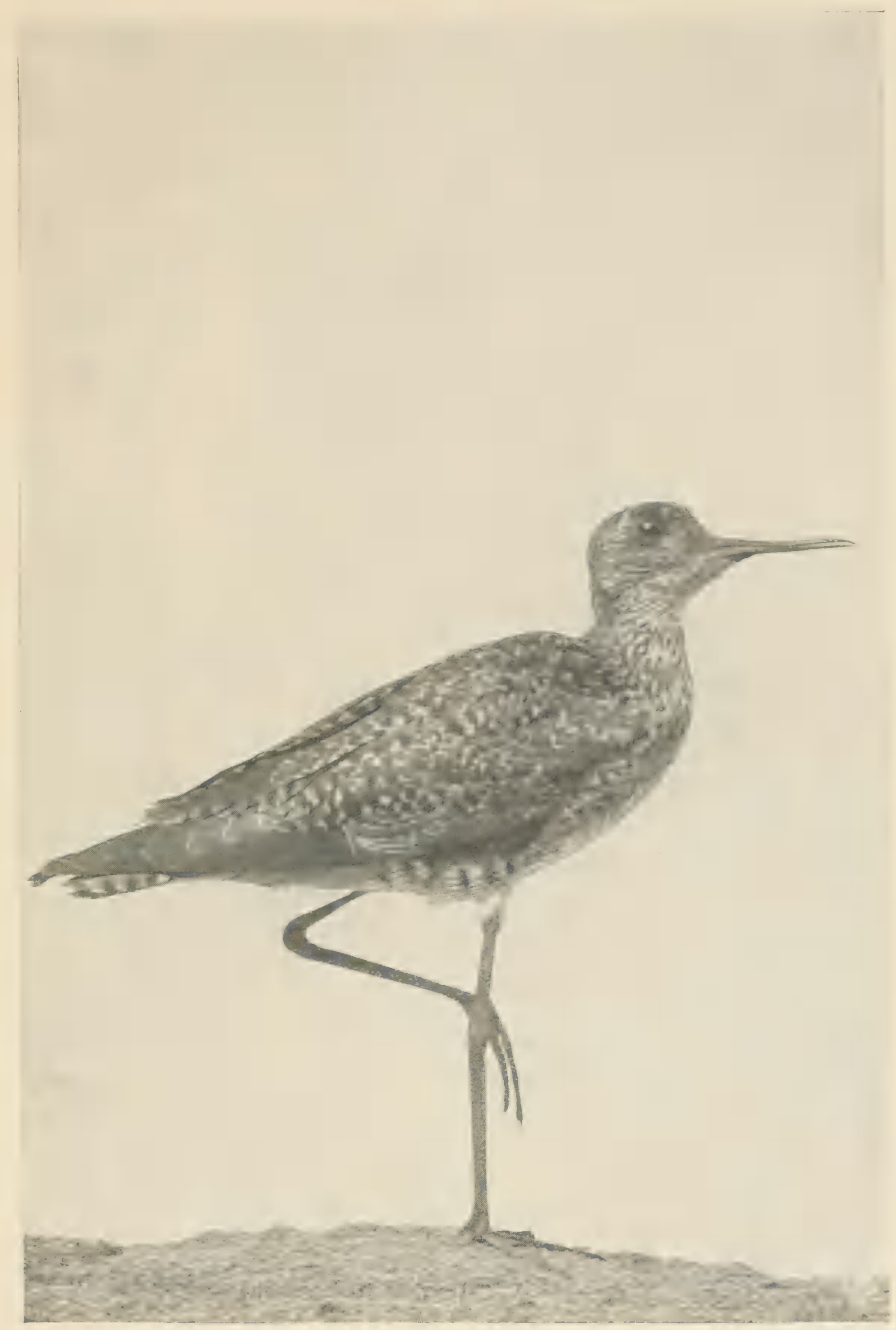

LESSER YELLOWLEGS 
ber. When a bird bends his leg, the toes are drawn up and held so. When he is sitting on a perch, he could not fall off if he wanted to.

Birds who have the "scratching foot," the second kind, mostly go about on the ground, or wade in the water. They do not usually sleep on perches, but sleep standing, or crouch on the ground. In the arctic regions, where there is a great deal of snow, some birds with scratching feet, who have to go about in it, have in winter what has been called "snowshoes," because it enables them to walk on the snow with ease. It is a web-like growth on the side of each toe, which serves the same purpose with birds that snowshoes do with men, keeps them from sinking into the snow.

Birds who have the "swimming foot," the third kind, have the toes made into a paddle by webs stretched between them. They are the water birds, - ducks, geese, gulls, and others.

The toes of all birds have long, sharp claws, not at all like our toe-nails. In the whip-poorwill and the nighthawk, one edge of the middle claw has teeth like a comb.

The long slim part above the toes, what we call the leg, is named in the books the "tarsus." The tarsus is generally bare, with a leathery skin; but in some hawks and owls it is covered 
with feathers. Birds who live away up in the cold have feathers down on to the toes.

On looking carefully at one of these bare legs, it will be seen that it is not smooth like a lead pencil. It is marked in a sort of pattern. Different species of birds show different patterns. Some look like the shingles on a roof; others like little squares or plates; and some are finer, like scales on a tiny fish.

These marks help in arranging birds in the books, as I said the patterns of the feather tracts do also. That is, all who have the same pattern are said to be related.

The legs of birds are not all of the same length for their size. Some who never go about on the ground, like hummingbirds, swallows, and swifts, have very short legs. Birds who walk and hop on the ground have them longer, and birds who wade in the water have the longest of all. 


\section{XXV}

HIS WINGS AND TAIL

A BIRD's wing does not look much like our arm and hand, yet the bones show that they are the same. The bird has a shoulder, elbow, and wrist, as we have. He even has fingers, though they are so covered up by feathers that one would never know it. He has not so many fingers as we have, and they are not movable like ours.

A bird's wing is a wonderful flying-machine, which men have been trying to imitate these many years. It is made of long stiff feathers, which fold down smoothly over one another at his side when he is resting, but can spread in an instant into a broad fan, to beat the air and carry him away.

One would not think that feathers could have so much power; but when the wing is spread, the barbs of the feathers hook together with tiny hooks, so small a microscope is needed to see them; and that, together with the edges lapping over each other, makes them almost like one solid surface. 
Wings are not alike in shape. The wing of a swallow is long and narrow, while that of a hen or grouse is short and round. We can tell by the shape of a wing how a bird flies.

A long, narrow, pointed wing shows that the

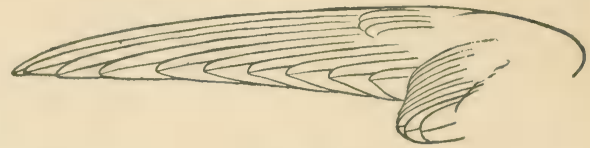

Fig. 11.

Wing of Swift.

bird has an easy, skimming flight, - either he flies great distances, or spends hours at a time on wing (Fig. 11).

The short round wing (Fig. 12) shows that a bird has a strong flight for short distances. These wings are

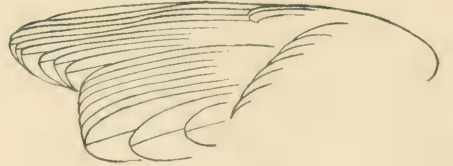

FIG. 1:.

Wing of sparrow. found mostly on rather heavy birds, like grouse.

The longest wings are seen on water birds, such as the petrel and the frigate-bird. The shortest, also, are found among water birds, those who swim more than they fly, as the auks.

All the feathers of the wing are named, and 
it will be well to remember that the long stiff quills are called remiges or "rowers." These are firmly rooted in the flesh, and are the hardest to pull out. They are the most important to the safety of the bird.

Birds have also another use for their wings. They are a strong weapon to defend themselves, or to fight others. A large bird can give a severe blow with his wing, and when pigeons fight, it is said they hold up one wing to protect themselves while they strike at the enemy with the other.

Sometimes serve as musical instruments. Woodcocks make whistling sounds with their wings as they $\mathrm{fy}$, and mourning doves

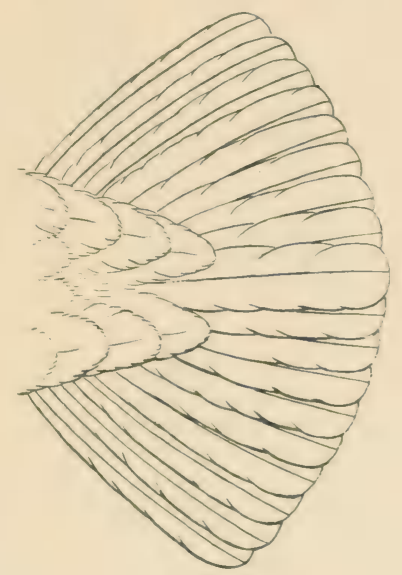

FIg. 13.

Tail of Ruffed Grouse.

Ruffed grouse produce with theirs a rolling drum-like effect, and others rattle theirs like castanets.

If wings are not used, they slowly get to be smaller and weaker, each generation having them more and more useless, till after a while they are 
of no use whatever, and the birds cannot fly at all. This has happened, it is supposed, to the ostrich family and to some

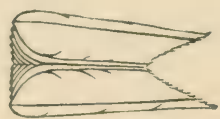

FIg. 14.

Tail of Vireo. birds living in the sea.

The tail of a bird is formed of an equal number of feathers in pairs, most often twelve. When spread they are the shape of a fan (Fig. 13), and when closed they lie over each other with the middle pair on top.

The tail feathers are not always of the same length, and that makes a difference in the shape of the end. Sometimes they are even (like Fig.

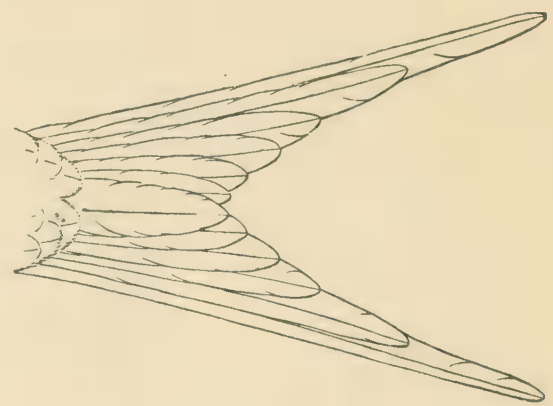

FIG. 15).

Tail of Swallow-tailed Kite.

14), when the tail is said to be "square." Sometimes the middle feathers are a little longer" than the outside ones, and then it is " rounded" 
or "pointed." If the outside feathers are longest, the tail is "forked" (Fig. 15).

The feathers of the tail are called rectrices, or " rudders," because they are supposed to be used to steer, or direct the bird's course in flying. But the tail is used also as a brake to check the speed in alighting.

The tail is used more than any other organ to express the emotions. Some birds, like the catbird and thrasher, keep it moving nearly all the time, jerking it this way and that, and tossing it upward.

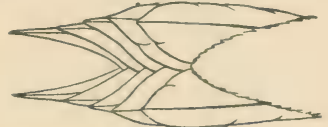

Fig. 16.

Tail of Sapsucker.

In woodpeckers and swifts the tail feathers are not soft at the end like others, but the stems or shafts project beyond the feathery part, and are stiff like the tail of a sapsucker (Fig. 16) or sharp like this of the chimney swift (Fig.

17). These birds use the tail as

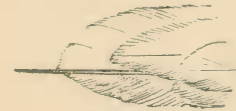

Fig. 17.

Swift Tail.

a prop to hold them against the tree trunk or chimney wall, and to help them in climbing.

Tail feathers are not so strongly rooted as wing feathers, and are easily pulled out. Sometimes, when a man or boy tries to catch a bird by the tail, the bird will escape, leaving his tail in their hands. 


\section{XXVI}

\section{HIS DRESS}

A BIRD's whole dress is made of feathers, but the feathers are not all alike. There are, indeed, several kinds of feathers, and four of them are found on every bird. There are flight feathers, clothing feathers, downy feathers, thread feathers, and powder-down feathers.

Feathers of all kinds are made in the same way. All have, first, a quill, the horny part next to the body; second, a shaft, the white part on which the barbs grow; third, the barbs, which grow out on each side of the shaft, and together are called the vane; fourth, the barbules, or little barbs, growing out of the barbs; and last, the barbicels, which grow on the barbules, and on the wings have the tiny hooks which hold them together.

But though feathers are made on the same pattern, they look very different. The wing and tail feathers are stiff and strong, and are called flight feathers, but those on the breast and body 


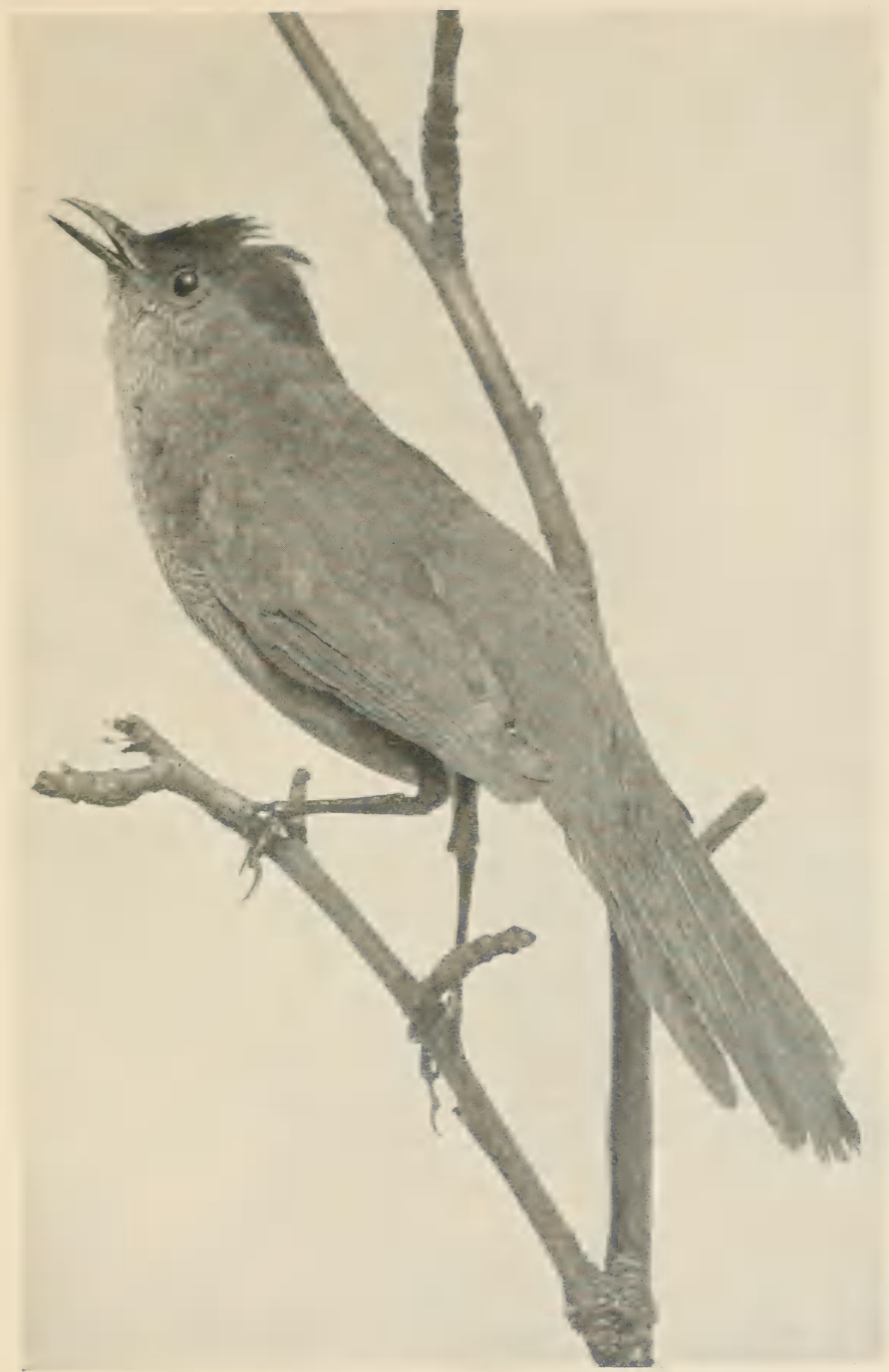

CATPIRT 

are soft, and cling closely to keep the bird warm and dry. These are the clothing feathers, because they clothe the bird.

Down feathers, which are almost always hidden under the clothing feathers, are, like their name, downy, and answer to our under-clothes.

Thread feathers grow anong the clothing feathers, and are almost like hairs. It is these that the cook singes off the fowls.

Kingfishers who dive, and ducks who spend much time on the water, have very thick down under the feathers - like suits of very warm under-clothes - which keeps the water away from their bodies. Thus they can dive, or sit on the water hours at a time, and not feel wet at all.

Powder-down feathers grow on some herons and cockatoos. They are called by that name because the tip ends are continually breaking off like white dust. Nobody knows their use.

Different from all these are the feathers called plumes, like the long, soft ostrich plumes we all know; the dainty little ones that stand straight up, and look as if the wind would blow them away; the long, showy feathers that the peacock spreads with so much pride, or even the pretty, drooping ones in the cock's tail.

These feathers are of no use for flight or for warmth, they rather hinder than help. They are 
for ornament, and there are many kinds among birds, all exquisitely beautiful. Nature has given to birds a more wonderful dress than to any other living creature.

It is with his feathers that a bird expresses his feelings. In anger he fluffs them out till he looks twice as big as usual; we have all seen a hen bristle up when a dog comes near her brood.

Nervousness or excitement is shown by jerking the wings and tail, and if a bird wishes to escape notice, he can make his plumage a perfect disguise. Mr. Bolles's pet owl would stretch himself up long and slim, with feathers hugging his body, when he looked so much like a broken branch of a tree that Mr. Bolles could hardly see him. And another owl that I heard of, when he was on the ground, would flatten himself and spread his plumage around, so that the eye could scarcely separate him from the dead leaves about him.

No one takes better care of his dress than a bird, and that is why it looks well for a year. Every day, with most birds, it is washed and carefully dried, each feather being passed through the bill, and the whole thoroughly shaken out. At night one may often see robins and catbirds before going to bed, dressing their plumage and shaking off the day's dust. 
Besides washing and drying the feathers, they need oil to keep them in best condition. For this purpose birds have a little "oil jug," a small gland over the tail, out of which, with the bill, they can squeeze a drop of oil. We often see ducks and geese oiling their feathers before a rain.

Water birds, who need a great deal of oil to keep out the wet, have the oil jug very large.

Birds seem to know perfectly well the beauty of their plumage. Not only do they try to show it off, as the peacock when he spreads his tail, but they seem to feel shame when their feathers are injured or soiled. One white feather coming in where it does not belong will make a bird very unhappy. He will work and tug at it to pull it out, and often make himself actually ill over the trouble. I had a captive bird who died, I think, from worry and work over a wing feather which persisted in coming in white, and which he insisted on pulling out every time. 


\section{XXVII}

\section{DIFFERENT COLORED SUITS}

A BIRD does not always wear the same colored dress, as I said in the chapter on moulting. A goldfinch, who through the summer wears a gay yellow coat, comes out in the fall in plain olive and black; and the scarlet tanager, who flourishes in the most brilliant red, changes to a quiet green in winter. Besides these, some birds wear at one season a spotted coat, and come out afterwards in one of plain colors.

Most of them change by moulting, as I explained, the old feathers dropping out and new ones of another color coming in; or, to speak exactly, the new ones growing out and pushing the old ones off on their tips. But some change color without moulting. All birds moult completely in the autumn, many moult partially in the spring, and some, as I said, change without moulting.

This last change of color is made partly by fading, and partly by breaking off the tips of the 
feathers, or what is called "abrasion." This is a curious process. I told you something about it in chapter vii. Certain feathers have edges different in color from the rest; as, for example, a black feather with tips of yellow. While the feathers are new and perfect, as they lie over each other like shingles on a roof, only the edges show, and these being yellow, the bird appears to be dressed in yellow. But the yellow tips are not so strong as the rest, and they break or wear off, or are pulled off in the spring. What is strange, they break exactly where the black begins. So as soon as the yellow is off, the black shows, and behold, the yellow bird suddenly becomes a black bird.

That is the way some birds manage to put on their spring dress in the fall. The solid color is the color of the spring, but it is hidden or veiled by tips of another color for winter.

The meadowlark changes in this way. In the winter his coat is brownish, or buff. In the spring these tips are worn or broken off, and he comes out in yellow and black.

Another change, even more curious, is made by some birds, who all winter wear white spots, or light scolloped edges to their feathers, and in spring the spots are gone.

In these, the white or light parts only break 
off, as sharply as if cut with scissors. They leave the edges of the feathers notched in queer ways, but as they lay over each other that does not show.

Birds in this way ean change color without changing their feathers. While moulting but once a year, they can show two suits, and by partially moulting twice, can show three suits.

Another thing about the color of feathers is interesting. Some colors, such as black, and red, and brown, are caused by coloring matter in the feather. But other colors are only an effect of the way the feather is made, whether it has ridges on it, or certain minute specks under the surface, which seem to act as prisms (says Dr. Newton), and reflect the light in different colors.

For instance, green is always due to some shade of yellow coloring matter under a surface full of lengthwise ridges, and other colors are made in similar ways.

These curious facts have been found out by that tell-tale little instrument the microscope, and no doubt it will reveal many more secrets in time.

Color is useful to birds, as well as beautiful. Its great use is to conceal them from their enemies, and they show that they know this by their conduct.

When a bird is the color of dead leaves, or 
Aneriun liobin 



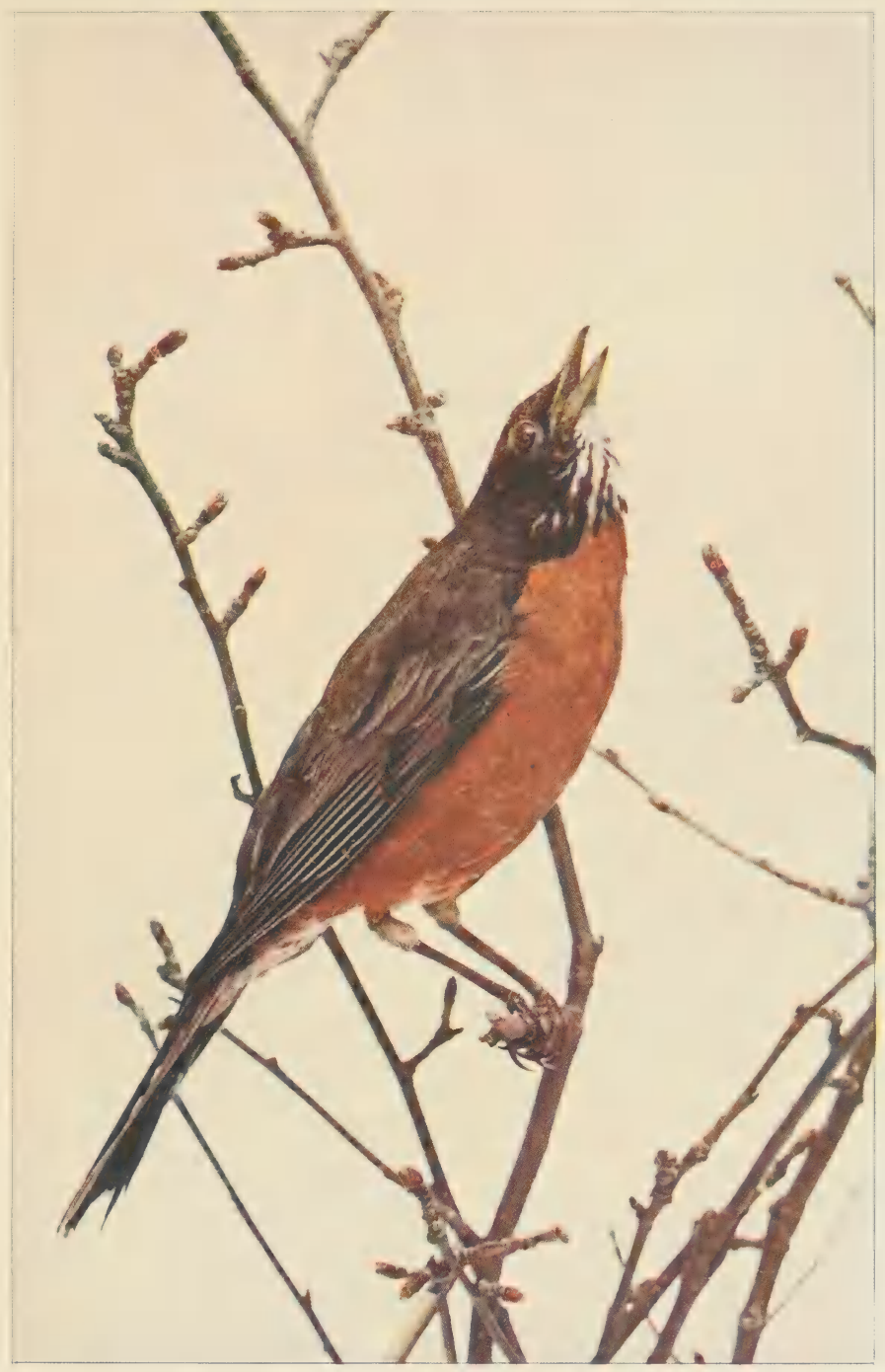



the sand, he has only to flatten himself and keep still, and he is hidden. Such a bird on the nest will often let one come close, and even stroke her, while relying on her color to be unseen. A sitting ruffed grouse will do so. But if snow falls, the same bird is very wild, for she knows she can be seen in the snow.

I have seen a striped bird, - black and white warbler, - when frightened, flatten himself on a branch, where he looked so much like the bark that he could not be seen.

Ground birds are mostly in mottled colors of the ground. The whip-poor-will, whose habit it is to rest on a $\log$ all day, wears colors that hide him as well as if he were under the log.

The striking colors on a bird are often hidden when he is at rest, but show plainly when he flies. When a flicker stands quietly on a fence he is all in rather dull colors, but when he flies he shows a large snow-white spot on his back, so that as far as one can see him he may be known.

A meadowlark on the ground looks not unlike a flicker, but when he flies he shows that the outside feathers of his tail are white. This is as striking a mark as the white spot on the flicker.

Many birds have such markings, and it is thought by men who study birds and look for a use in everything, that such marks serve the 
purpose of "danger signals" or " recognition marks." That by these birds can know each other in the dusk, or that the flash of color will catch the eye, when the bird does not wish to give a call, but to slip away quietly to avoid danger, and at the same time to give notice to other birds to do the same. 


\section{HIS RELATIONS WITH US}





\section{XXVIII}

HOW IIE WORKS FOR US

Many times in this book I have spoken of the great value of the services of birds, in helping us destroy insects and weeds that injure our crops. But there is more to be said about it.

From morning till night, almost the whole of his life, nearly every bird is working for us. He does not know he is working for us, of course. He is simply hunting for the food he likes, and what is good for young birds to eat.

But what he chooses to eat himself, and to feed the young, consists mostly of creatures that destroy our fruit and vegetables, caterpillars that eat the leaves off our trees, worms that get into our apples and berries, beetles that spoil our roses and our potatoes, mice that eat our crops, and all the worms and grubs that gardeners and farmers are all the time fighting.

As I have already said, some of the birds like cherries and green peas, and other things we prefer to keep for ourselves. But we should 
never forget that they have earned, by their work among the worms, all they can take.

I say this, not merely because I love the birds, and want to have them live and be happy, but because it is true. It has been proved true by scientific men in the service of the United States government.

These men have had thousands of birds killed to see what they were eating; and they have found out that nearly every bird they have examined - blackbirds, cedar-birds, blue jays, hawks, owls, even crows - do us more good by the injurious creatures they destroy, than harm by the fruits and vegetables they eat. To this there is, among the small birds, but one exception, the English sparrow, and, of the large ones, only the two hawks and one owl, mentioned on page 53.

Chickadees like to eat the eggs of cankerworms ; and for a single meal, one of these tiny birds will eat two hundred and fifty eggs, and he will take several meals a day. Now cankerworms destroy our apples. When they get into an orchard in force, it looks, as Miss Merriam says, as if it had been burned over.

Robins, eatbirds, and shrikes, and several others, like to eat cutworms, which destroy grass and other plants. As many as three hundred of them have been found in the stomach of one 


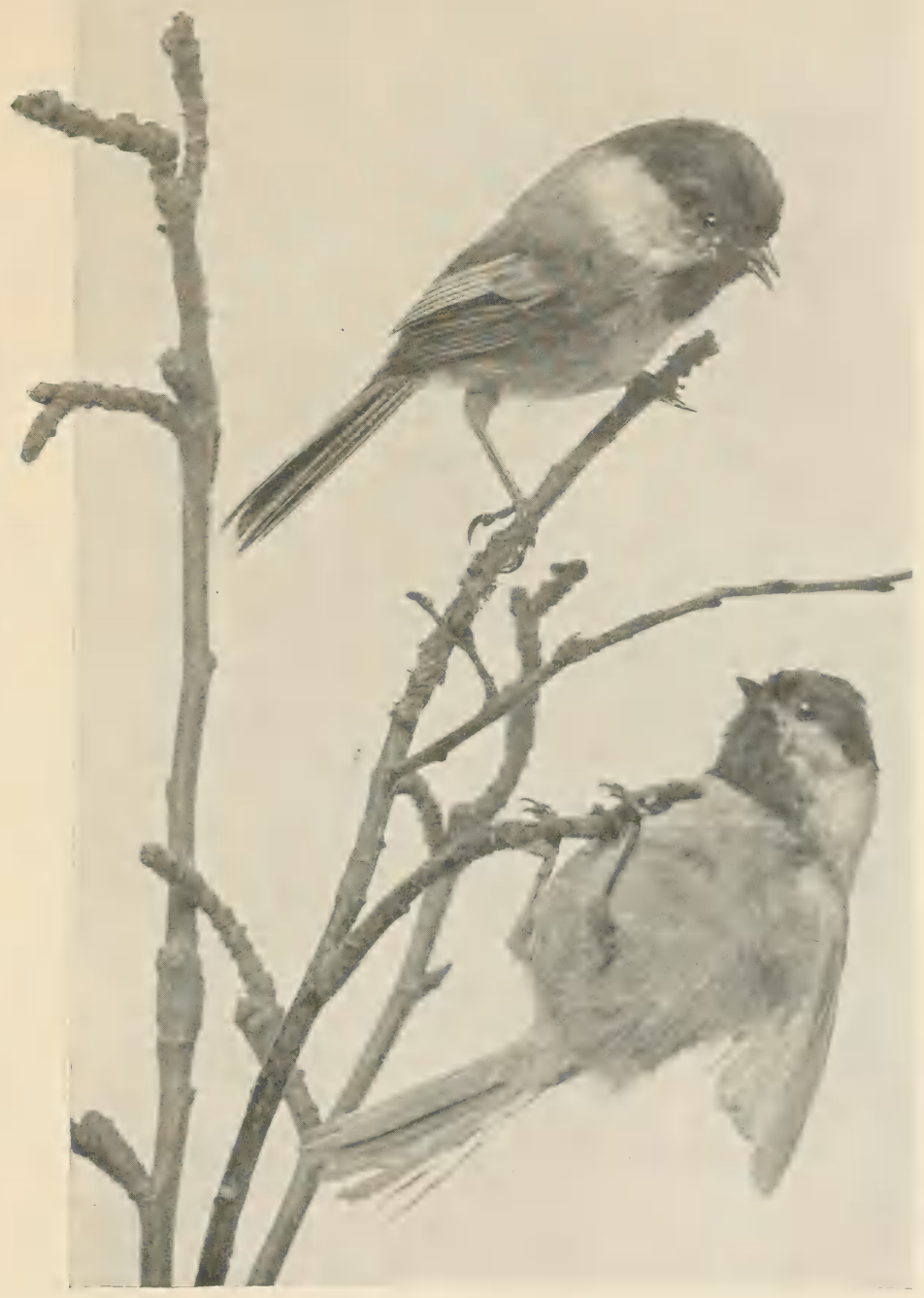

BLACK-CAPPED CHICKADEES 

robin, of course for one meal. Ants are very troublesome in many ways, and three thousand of them have been taken from the stomach of one flicker.

Rats and mice, ground squirrels and gophers, make great havoc in our crops, and farmers spend much time and labor trying to get rid of them; but these creatures are the favorite food of most hawks and owls.

If the farmer would stop shooting the birds, and protect them instead, they would do this work for him, and much better than he can. But because (as I said in a former chapter) one or two hawks and owls have a taste for chickens, he generally kills every hawk and owl he sees, and for this folly has to spend half his time trying to kill the little animals they would gladly have eaten.

A great deal of refuse, dead sea creatures, and other matter, is thrown up on the seashore, or floats on the water. On this feed the water birds, - herons, gulls, terns, and others. If this were not disposed of, it would make us sick. Indeed, on the shores where so many herons have been killed, to get their plumes for ladies' hats, the result has been sickness and death among the people, as Dr. Gaumer, of Yucatan, told Mr. Chapman. 
Besides the work they do for us in destroying animal life, their seed-eating is almost as useful. As I said, they eat the seeds of weeds that farmers and gardeners are all the time laboring to keep down, so that useful plants may have a chance to grow.

The whole family of finches, sparrows, buntings, grosbeaks, and all birds with the high, thick bill, though they eat largely of insects through the summer, and feed their nestlings on them, when insects get scarce and weed seeds are ripe, they turn to them for food. They eat the seeds of all kinds of troublesome weeds; and as each single seed might produce a plant, we cannot guess how much they destroy.

Professor Beal, who is at the head of this government inquiry into the food of birds, and who knows what he is talking about, says that one species of little bird - the tree sparrow - destroys every year in one of the Western States, many tons of the seeds of weeds.

There is a curious and interesting fact about this seed-eating. The regular seed-eaters, the finches, prefer the seeds of weeds that are mostly harmful, and these they break up, taking off the shells, and of course destroying the germ, making it impossible for them to grow.

But there are many birds who eat berries hav- 
ing in them seeds, such as raspberries, blackberries, and all kinds of wild fruit. These birds do not crack the seeds; and, as they are hard, they do not digest in the stomach, but are dropped whole, and are ready to grow wherever they fall.

Thus, while seed-eating birds destroy the weeds which are hurtful, the fruit-eaters plant the seeds of berries and fruit which we like. That is why we find wild berry bushes all over the country. We have to thank the birds for it.

A great deal more could be said about the birds' work for us. Not only the robins and those I have spoken of, but cedar-birds, who are shot because they take part of our cherries, blackbirds, because they eat some grain, orioles, because they occasionally take green peas, and kingbirds, because they have the name of eating bees, though it has been proved that they eat only drones, which have no sting and make no honey.

Let me impress upon you two facts. First, that the harm said to be done by birds is often mere guesswork, from careless observation. For instance, a man seeing a bird going over his blossoming fruit-trees, at once concludes he is destroying the fruit, probably shoots him, and then writes to his favorite paper that a certain 
bird eats fruit buds. Other papers copy it, and a war against that bird begins in every orchard.

Whereas, the truth is, the bird was preserving the fruit by picking out the insects that would have spoiled it. This is no fancy picture; this very thing has happened more than once.

And again, whatever is said about the harm this or that bird does, never forget this second fact, which I repeat, and which may be relied upon as perfectly trustworthy. The officers of the government of the United States, who have carefully studied the matter and found out positively, without guesswork, what birds eat, have declared emphatically that every bird they have examined does more good by destroying pests, than harm to our crops, excepting only the bird we have imported, - the English or house sparrow. 


\section{XXIX}

HOW TO ATTRACT HIM ABOUT OUR HOMES

Because birds are so useful to us, as well as because they are so interesting and so beautiful, it is delightful to have them come about our homes. And it is not at all difficult, for they are easily taught to like us.

In countries where people are gentle, and try to make birds happy, instead of shooting them or throwing stones at them, they become very tame. Mr. Hearn, who has written about Japan, says that the fearlessness of wild creatures is one of the most charming things about the remote parts of Japan, "where tourists with shotguns have not yet come."

Travelers who visit Norway tell us that birds are never disturbed there, and they come freely about the houses. When it is very cold they even come into the houses for food and warmth, and no one thinks of frightening them or trying to catch them.

Even in our own country, Dr. Ridgway told 
me of a bird-lover in Florida who would not let birds be annoyed on his place. As a result he had a great many there, and they became very tame. Cardinal grosbeaks, who are rather shy, were so tame they would take food from his hand.

A person living in the country, wishing to draw the birds about his place, should begin by protecting it. Cats should not be allowed to come near, English sparrows should be kept down, and boys who shoot or throw stones should be banished from the vicinity.

Next, trees and shrubs that birds like, for nesting and for food, should be set out. For nesting, a very attractive place for the smaller species is a thick hedge of bushes, the thicker and closer the better.

Nesting-boxes nailed up in trees please many, and evergreen trees will draw some that would not come otherwise. For food, various berrybearing shrubs and trees should be provided, such as chokecherry, shadberry, mulberry, and others.

In a town or city, besides shrubs that birds like, a high fence, with a top that cats cannot walk on, is desirable, and a readiness to go to their assistance is soon appreciated.

A friend told me a few days ago of a family 


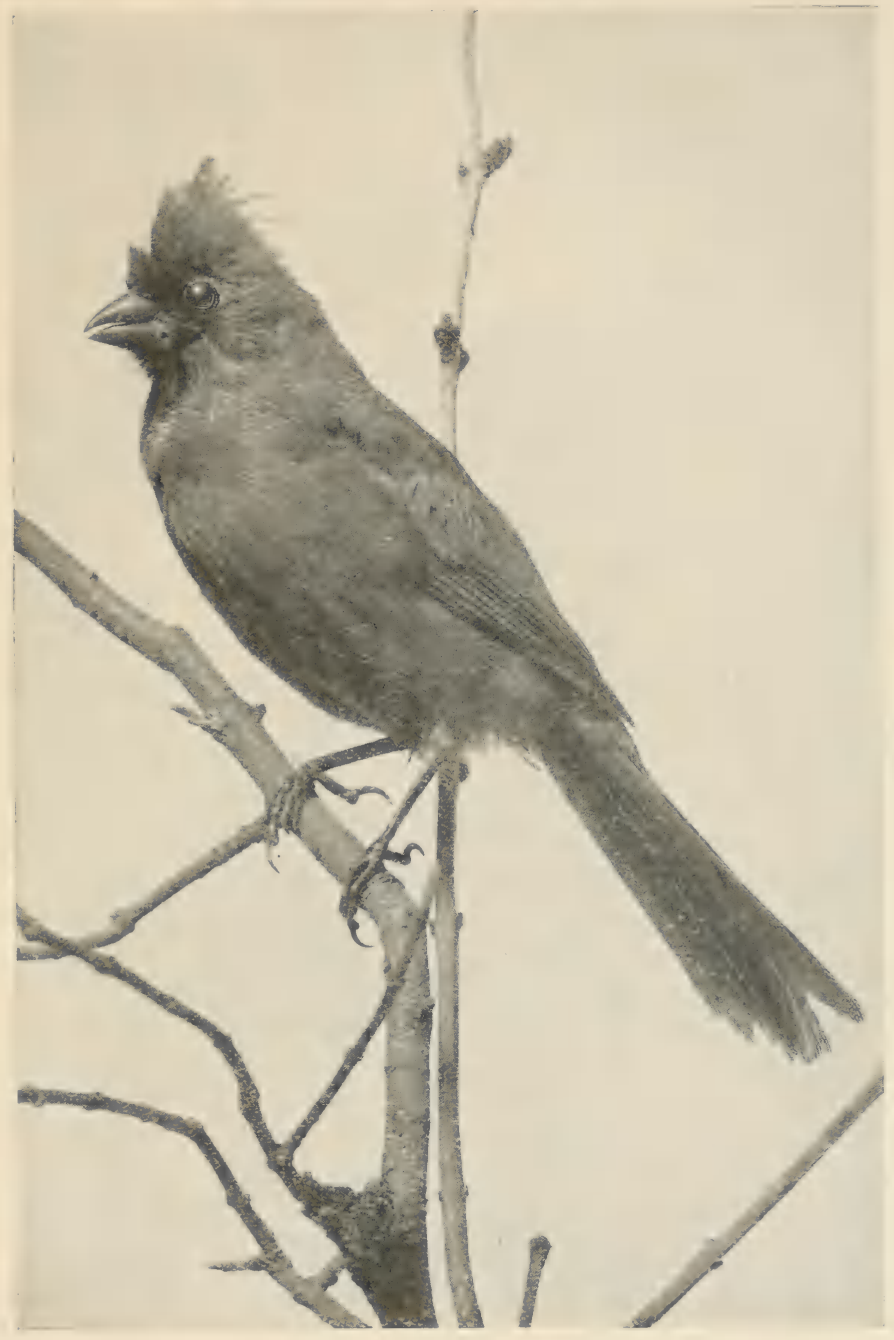

CARDINAI 

of wood thrushes who nested last summer in the yard of her house in the city of Orange, N.J. The birds soon found out that some of the family would come to drive away strange cats which came in. After they learned that, when a cat appeared they would give a peculiar cry, unlike any other heard from them. On hearing this, one of the family always hurried out and drove the enemy away.

If the birds could not get any response from a call at the kitchen door, they would fly to the front of the house, perch on the piazza rail, and call till some one came out. All through nestingtime they thus called on their friends for protection, and the delight the family had over the nest and the friendly birds amply repaid them for their trouble.

The one great necessity, in both city and country, is water for drinking and bathing. It should be in a shallow dish. The rough saucer of a flower-pot is best, because the bird's feet do not slip on it, and the edge is broad and round and easy to perch on.

Next best is an earthen dish, with clean pebbles in the bottom, to avoid slipping, which frightens them. Water should never be more than two inches deep, but should always be clean, and fresh two or three times a day. 
No food should be offered in summer, because we want them to get their natural food of worms and seeds.

In the winter it is different. They should have food regularly. But once used to having their wants supplied, they will depend upon it, and suffer and probably starve, if they are neglected or forgotten. So one should be very sure he will not get tired of it, before he teaches them to expect food.

To feed them safely, a shelf must be placed out of the reach of cats and bad boys. On the sill of a window is a good place, or the roof of a piazza, or a little balcony. Breakfast should be served to them at the same hour every day, and they will soon know when to come for it.

For food, they will eat any table scraps of meat, and vegetables, and bread, chopped fine, and most kinds of grain, broken up, or crushed, for the smaller birds.

But the thing they all like best of everything is raw suet, as it comes from the butcher. A large piece may be wired or nailed in place, so that it may be picked at and not displaced, or it may be chopped fine and scattered on the shelf, like other food. All birds are fond of this.

In winter they need water, and it should then, also, be fresh. 
A lady living in southern Ohio, who has for several years given a breakfast to the birds every day in winter, told me that her daily guests last season were hairy and downy woodpeckers, nuthatches, white and red-breasted, one young kinglet, a pair of chickadees, tufted titmice, blue jays, juncos, cardinal grosbeaks, Carolina wrens, and sparrows.

This delightful company came regularly for breakfast, and to pay her, sang nearly through the season.

In the latitude of New York there are about forty birds who spend the winter, and of course there are more as one goes south. In the Southern States, many of our northern birds may be studied in the winter. 


\section{XXX}

HOW TO STUDY HIM

An attractive thing about bird study is the fact that there is still so much to be found out.

Men have been studying the dead bird for many years. All about the body is well known. The way he is made, the arrangement of his bones and his organs, are plainly set forth in the books, in words and pictures.

The shape and colors of his plumage, how many feathers belong to his wing and tail, his length, his extent, the shape of his beak and his foot, - all these facts are to be found in every Ornithology.

Some of his most easily noted habits, too, are familiar; where and when he nests, where he spends his time, and where he goes in the winter, what he eats, and when he changes his dress.

But really to know the living bird, to make acquaintance with the individual, to see his family life, his manners, his intelligence, his powers, - this kind of study has hardly begun. . 
This almost new and most attractive field is open to us to-day. It offers a charming study, with the added interest of discoveries to be made. Nor is it so hard as most persons think.

In the beginning there are two things to learn : first, how to study from life; and second, how to identify without killing. To study is simply to observe closely and carefully, and to report accurately.

Take a little lesson in observing: When you see a bird do not merely gaze idly at him, but take note of everything about him. What he is doing, how he is doing it, and all his points, his size and shape, his colors and markings.

If he is getting food, as he most often is, see whether he picks it from the tree trunk or gathers it from grass tops; whether he hunts it among leaves, bores the bark, drops to the ground, or sails out into the air for it.

Then try to discover what it is - insect or seed, beetle, grub, or worm - and what he does with it, - swallow it at once, beat it to death, or hold it in his mouth uneaten.

Then notice his manners, - if he stands still, or jerks his tail or body; if he flits about the branches, hovers before a flower, or hammers at the door of an unlucky grub behind the bark. Next, does he walk or hop? does he chatter or 
keep silent? fly straight, or go bounding in great waves through the air? All these things you must learn to see, and to note down the moment you do so, so that you will not be uncertain or confused when you take your books to see who he is.

Then you must take note of his size, and to do this - as it is hard to judge of inches - it is well to have in mind a sort of index of size to which you can compare him. Take the most common and best-known birds for standards, the robin, the English sparrow, and one smaller, the wren, or the "chebek" (least flycatcher). When you see a bird, if he is as big as a robin, enter in your note: "Size, robin." Should he be a little smaller, yet still larger than your measure, - the English sparrow, - you can note it, "Size, robin - ," the minus sign meaning that it is less. If he were larger, you would put the plus sign: "Size, robin +."

Observe the shape, whether it is slim like an oriole, or chunky like a chickadee; also any peculiarity of plumage, as a crest, specially long or strangely formed tail feathers; the end of the tail, whether square, rounded, pointed, or notched.

Then the beak; its length compared to the head, its shape and color. If it is high and 
thick, like a canary's or sparrow's, the bird is a seedeater; if long and straight, like a robin's, he is an insect-eater; if sharp and flat, opening very wide like a swallow's, he is a flycatcher.

Lastly, the plumage, the general color, then the special markings, such as bars on wings or tail, a ring around the eye (Fig. 18), or a line over or through the eye (Fig. 19), white or black throat (Fig. 20 or 19), speckled or striped breast (Fig. 18), or any conspicu-

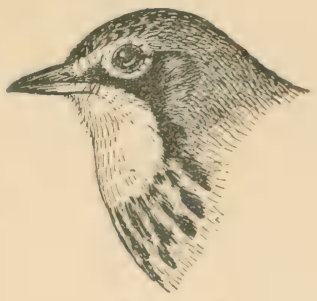

FIG. 18.

Canadian Warbler.

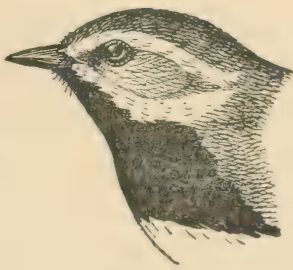

Fig. 19.

Black-throated Green Warbler.

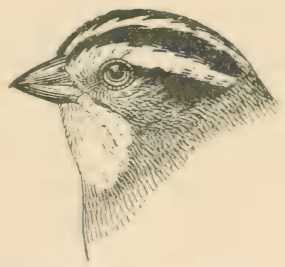

FIG. 20.

White-throated Sparrow.

Many persons think that in order to know a bird, and especially to find out his name, one must have him in the hand, 
count his wing and tail feathers, and measure his length. Excepting for exact scientific purposes, this is not at all necessary. Almost any bird in America may be perfectly identified without touching him, indeed, while he is in the enjoyment of his liberty in a tree. For birds have marked external differences, which are carefully set down in the books.

The modern manuals, too, are usually furnished with a color key, the use of which is fully explained in them. With the help of these you will have little trouble in naming him.

Above all, be exact in your knowledge and do not jump at conclusions. If you see a bird on a fruit-tree picking about the blossoms, do not decide offhand that he is spoiling the fruit; look closely to see if he is not, instead, clearing it of worms that would destroy it all. When you notice a bird in a strawberry bed, do not instantly conclude that he is after strawberries; he does n't care half so much for berries as he does for insects, and very often he is engaged in ridding the plants of pests, at the moment that he is scared off or shot by a careless person, who does not wait to see whether he is friend or foe.

Although patience and clear eyes alone will open many delightful secrets of bird life, a good opera glass will do still more. It will bring you 


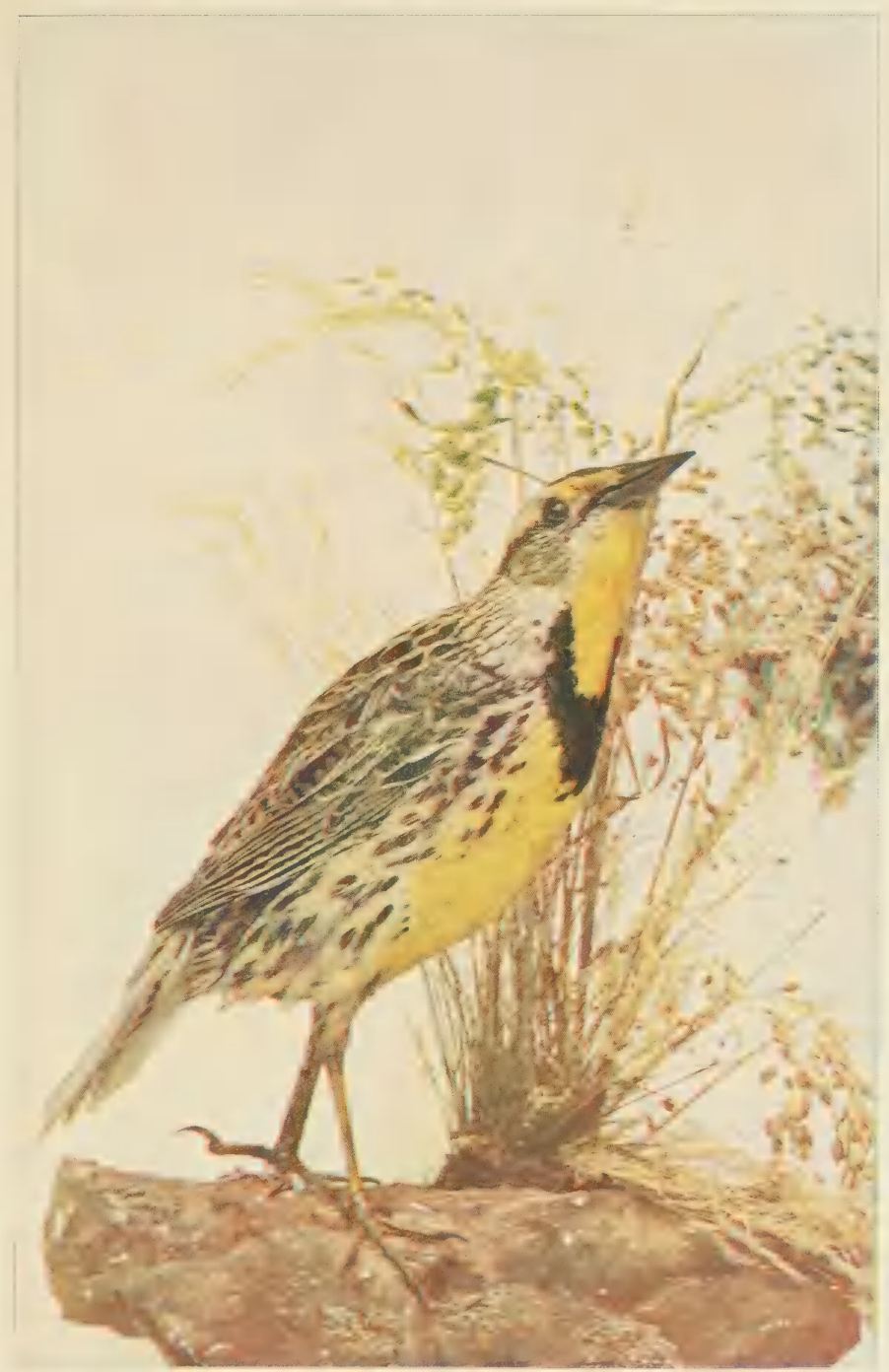

Meadowlark 

nearer to the bird without frightening him. You can see thus much better, not only his markings, but what he is doing. In a word, you can be more sure of your facts.

In deciding upon the actions of a bird, never greess at anything. If you see a pair very busy about a shrub, you may be sure they have a nest there, but do not so record it till you have actually seen the nest. Even then you should not conclude at once that it belongs to them; I have seen birds sit a few moments in nests which did not belong to them - as if to try them. You may feel very sure what a bird means by an action, but you should set down only what he does. Without this care, your records will be worthless.

Do not discourage yourself by trying to find the name of every tiny atom in feathers that you see; indeed, little birds flitting about the treetops - mostly warblers - will be hard for you to identify, and almost impossible to watch. I advise you to confine your study at first to the larger and less lively birds, - kingbirds, robins, thrushes, phøebes, bluebirds, orioles, goldfinches, and others, all of which you will find near to houses and easy to study. Do not expect too much at once, nor give up in despair if you cannot identify the first bird you see. 
You may be sure that every hour you honestly give to the study will make it more interesting; every bird you learn to know will be like a new and delightful companion.

You will lose your desire to take life or even to steal eggs from them; the country will have new charms for you; in fact, a person blessed with a love of the study of birds or beasts or insects possesses a lifelong and inexhaustible source of interest and happiness.

In regard to a manual, there are now so many to be had, one hardly knows how to select. I will mention only two or three, which have particular points of value.

A good book to begin with, for residents of New England, New York, and the Eastern Middle States, is Professor Willcox's "Land Birds of New England" (Lee \& Shepard, Boston. Price 60 cts., by mail).

Although this little book treats of only ninety birds, they are the most common, and its value is its simplicity, and the ease with which its color key enables one to identify the birds it treats. It introduces a beginner to the larger works in a most pleasing way.

A good general work for Eastern North America, thoroughly trustworthy and not too technical in its use of terms, treating all the 
birds of the locality, is Chapman's "Handbook of the Birds of Eastern North America" (Appleton, New York. Price $\$ 3.00$ ). It has a color key and a color chart, by which one may see what is meant by colors named.

Especially attractive to ladies and amateurs, for its charming accounts of bird life, is Mrs. Wright's "Birderaft" (Macmillan, New York. Price, \$3.00). It treats but two hundred species, but that includes the birds usually seen in the New England and Northern Middle States. It has a color key.

The whole United States is covered by Dr. Coues's "Key to North American Birds," latest edition (Estes \& Lauriat, Boston. Price \$7.50). It is not quite so easy for the beginner, but it is untechnical in style, and fully illustrated.

One book deserving mention because of its value as an aid to teachers is Miss Merriam's "Birds of Village and Field " (Houghton, Mifflin \& Co., Boston. Price \$2.00). It is exceptionally rich in facts and statistics relating to the economic value of birds. It treats nearly two hundred of the most common birds.

A book intended for identification only is Professor Apgar's " Birds of the United States" (American Book Company, New York. Price $\$ 2.00$ ). It is the result of his experience as 
teacher, and has several new features very helpful to beginners, such as small cuts at the bottom of pages to explain terms, thus showing exactly what is meant, for example, by "wing bars" or "rounded tail." It also gives hints about the usual locality of a bird, whether creeping over a tree trunk, on the wing, or elsewhere. It takes particular note of size, having one section for birds about the size of an English sparrow, and so on. The pronunciation of the Latin names is carefully indicated. There are several chapters giving descriptions of the external parts of a bird, and there is a glossary of scientific terms.

The following list of points to observe in watching birds has been used to advantage by classes in bird study. A little familiarity with this will help one to remember what to look for. A similar, but fuller and more elaborate, list has been prepared, and bound up in tablets, to use in the field. It is for sale by Miss J. A. Clark, 1322 Twelfth Street, N. W., Washington, D. C. 


\section{POINTS TO OBSERVE}

1. Locality - tree : bush : ground.

2. Size - compared to robin: English sparrow.

3. Form - long: short : slender : plump.

4. Beak - high : stout : wide: hooked : long: lobes : drawn down.

5. Tail - length : shape at end.

6. Legs - long: short: scales.

7. Toes - webbed : how turned: hind claw long.

8. Color - bright : striking: dull : plain.

9. Markings - on head : breast : wing: tail : back.

10. Manners - walk: hop : quiet: active : noisy : silent. 11. Habits - eating seeds : berries: insects: from ground: tree trunk: leaves.

12. Song - long : short: continuous : broken.

13. Flight - direct: undulating: fluttering: labored.

14. Nest - where placed : shape : materials : eggs.

15. Young - plumage : behavior. 



\section{INDEX}

AfFections, 78-82.

Air-saes, 92, 94 .

Arrival in spring, 3, 4 .

Attraction and protection of birds, 131135.

Audubon, John James, 60.

Auks, 110.

Beak, 95-97.

Blackbird, crow, 72 .

Blackbirds, 3, 126, 129.

Bluebird, arrival, 3 ; getting food for young, 17 ; teaching young to $\mathrm{fy}, 37$, 38 ; feeding, 50.

Bobolink, nest of, 9 ; one of the first birds to stop singing in summer, 47 ; the fall migration, 61,62 .

Bob-white (quail), 44, 59 .

Body, shape of, 91.

Bolles, Frank, his pet owl, 101, 116; his story of a heron, 103, 104 .

Bones, 92, 94.

Books about birds, $142-14 t$.

Brooding, 13-16.

Buzzard, turkey, 50, 51.

Canary, 20, 57, 81.

Cardinal, 69, 132.

Catbird, food of, 49, 126; jerking the tail, 113.

Cedar-bird, feeding young, 19 ; story of affection for young, 78 ; usefulness to man, 126, 129 .

Chewink, 76,77 .

Chickadee, defending eggs, 11, 12; getting food for young, 18; as an eater of insects' eggs, 68, 126 ; affection for young, 78 .

Color in feathers, 120. See Plumage.

Cormorant, 94.

Crop, 93.

Crossbill, 97 .

Crow, punishing a young one, 37 ; sleeping in flocks, 59,60 ; story of an affectionate, 80 ; usefulness to man, 126.

Down, the first plumage, 15, 21, 22, 115.

Ducks, 97, 115.

Ears, 102-104.

Eggs, beauty of, 11 ; the mother's care, 11,12 ; incubation and hatching of, $13-15$.

Eyes, 100-102.

Feather tracts, 22, 23.

Feathers, their first appearance on the young bird, 22 ; of the wing, 109-111; of the tail, 112, 113 ; the various kinds of, 114,115 ; expression of emotions by, 116 ; the birds' care of the, 116 , 117. See Plumage.

Feet, 92, 105-108.

Fish, birds and dead, $86,87$.

Flicker, method of feeding young, 18; food of, 85, 127; color markings, 121. Flying, 93.

Food, 48-55; in winter, $67-69,134$; in its relation to the welfare of man, 125-131).

Frigate-bird, 110. 
Geese, 98, 99.

Gizzard, 93.

Goldfinch, American, 14 ; story of canary and, 20; change of color, 26 ; food, 54 ; flocking, 71 .

Goldfinch, European, 79.

Grouse, 58, 59, 110.

Grouse, ruffed, 111.

Gullet, 93.

Gulls, 101.

Hawks, food of, 52, 53, 126, 127 ; asleep, 59 ; beaks of, 97 ; eyesight of, 101 ; feet of, 106.

Heligoland, 101.

Herons, food of, 53,127 ; bills of, 97 ; story of the hearing of a heron, 103, 104 ; usefulness to man, 127.

Hummingbird, ruby-throated, absence of male from nest, 16; method of feeding young, 18.

Hummingbirds, 15, 98.

Identification, 137-141.

Indigo-bird, 47.

Instinct, 83.

Intelligence, 83-87.

Japan, 131.

Jay, blue, learning to $\mathrm{fly}, 31,32$; storing food, 54 ; story of a mischievous, 55 , 56 ; usefulness to man, 126.

Kindness of birds to each other, $7 t-77$.

Kingbird, 14, 129 .

Kingfisher, 21, 115.

Language, 43-47.

Legs, 92, 105, 107, 108.

Meadowlark, 45, 119, 121.

Migration, 61-68.

Mockingbird, 45.

Moulting, 25, 26, 118.

Neck, 92.

Nests, situations of, 9; materials of, 9, 10 ; building of, 10 ; seldom used more than once, $10,11$.
Nighthawk, 107.

Norway, 131.

Nuthatches, 18, 96, 98.

Observation, 137-141, 145.

Oil, 117.

Oriole, nest of, 9, 95; getting food for young, 18 ; teaching young to $\mathrm{fly}, 33$, 34 ; food of, 50 ; affection for young, 78 ; usefulness to man, 129.

Ostrich, 24.

Ostrich, South American, 24.

Owl, barred, 101.

Owls, 35 ; food of, $52,53,127$; ears of, 103 ; feet of, 106 ; usefulness to $\operatorname{man}$, 126,127 .

Penguin, 72.

Petrel, 110.

Pewee, wood, 47.

Phoebe, 35.

Pigeons, 79, 80.

Plumage, the nestling, 22, 23 ; coloration of, 23, 24, 27, 28; moulting, 25, 26, 118; change of color without moulting, 26, 27, 118-120; protective coloration of, 120,121 ; recognition marks in, 121, 122 .

Protection and attraction of birds, 131135.

Quail (bob-white), 44, 59.

Redstart, American, 14.

Regurgitation, 18, 19.

Rhea, 24.

Robin, American, arrival, 3 ; 10, 15, 17, 18,21 ; plumage of young, 23 ; 34 ; teaching young to bathe, 38,39 ; notes of, 44,45 ; food of, $49,126,127$; roosting in flocks, 60 ; devotion to young, 78 ; story of the intelligence of a, 84 ; 102: usefulness to man, $126,127,129$.

Sapsucker, 85 ; tail of, 113.

Shrikes, 126.

Sleeping, 57-60.

Song, 14, 44-47.

Sparrow, chipping, 54. 
Sparrow, English, learning canary's $\mid$ Warbler, black and white, 121.

song, 46; young fed by a wren, 81 , 82 ; harmfulness of, $126,130,132$.

Sparrow, song, arrival, 3 ; nest, 9 ; individuality in songs, $45 ; 47$.

Sparrow, tree, 58, 128.

Sparrow, white-throated, 54.

Sparrows, 8t, 97 .

Stomach, 93.

Swallow, bank, 96 .

Swallow, barn, 71, 96 .

Swallow, eave, 71 .

Swallows, food of, $17,35,50$; flocking, 62,71 ; story of young, 75 ; story showing intelligence, 85 ; wings of, 110.

Swift, chimuey, sleeping, 59, 60 ; devotion to young, 78 ; tail of, 113.

Tail, 112, 113.

Tanager, scarlet, 79 .

Thrasher, 113.

Thrush, wood, 133.

Tongue, 97, 98.

Usefulness of birds to man, 125-130.

Veery, 47 .

Vireo, red-eyed, 47
Warbler, yellow, 50 .

Warblers, 62, 97.

Water, birds in, 94; for drinking and bathing, 133, 134.

Whip-poor-will, 107, 121.

Wings, 109-112.

Winter, birds in, 66-69.

Woodcock, beak of, 96 ; whistling sound of wings, 111.

Woodpecker, downy, 50 .

Woodpecker, red-headed, 85 .

Woodpecker, yellow-bellied, 85.

Woodpeckers, 18, 21; teaching young to feed itself, 35,36 ; food of, 50 ; storing food, 54, 55; sleeping, 59 ; 85 , 86 ; beaks of, 95 ; tongues of, 98 ; 103; feet of, 106 ; tails of, 113.

Wren, house, 81, 82 .

Young birds, hatching of, 13-15; feeding of, 16-20; first plumage of, 2123 ; learning to fly, 29-34, 37-39; the mother's anxiety about, 30-32; learning to feed themselves, 34-36, 39; learning to sing, 36 ; after leaving the nest, 70-73. 
ILECTROTYPED AND PRINTED

BY H. O. HOUGHTON AND CO

Che liturerion prests

CAMBRIDGE, MASS., U. S. A. 


\section{BOOKS ABOUT BIRDS}

PUBLISHED BY

\section{HOUGHTON, MIFFLIN AND COMPANY}

\section{FLORENCE A. MERRIAM}

BIRDS OF VILLAGE AND FIELD. For Beginners. Illustrated. $12 \mathrm{mo}, \$ 2.00$.

A-BIRDING ON A BRONCO. Illustrated. 16mo, $\$ 1.25$.

BIRDS THROUGH AN OPERA-GLASS. Illustrated. $16 \mathrm{mo}, 75$ cents.

$$
\text { JOHN BURROUGHS }
$$

WAKE ROBIN.

SIGNS AND SEASONS.

WINTER SUNSHINE.

BIRDS AND POETS.

FRESH FIELDS.

LOCUSTS AND WILD HONEY.

RIVERBY.

PEPACTON. A Summer Voyage.

Each volume, 16mo, $\$ 1.25$.

\section{FRANK BOLLES}

AT THE NORTH OF BEARCAMP WATER. 16mo, $\$ 1.25$.

LAND OF THE LINGERING SNOW. 16mo, \$1.25. CHOCORUA'S TENANTS. Poems. $16 \mathrm{mo}, \$ 1.00$. FROM BLOMIDON TO SMOKY. 16mo, \$1.25. 


\section{OLIVE THORNE MILLER}

THE FIRST BOOK OF BIRDS. Illustrated. Square $12 \mathrm{mo}, 75$ cents.

UPON THE TREE-TOPS. Illustrated. $16 \mathrm{mo}, \$ 1.25$.

A BIRD LOVER IN THE WEST. 16mo, \$1.25. BIRD WAYS. $16 \mathrm{mo}, \$ 1.25$.

LITTLE BROTHERS OF THE AIR. 16mo, \$1.25.

IN NESTING TIME. 16mo, $\$ 1.25$.

\section{BRADFORD T'ORREY}

BIRDS IN THE BUSH. \$1.25.

SPRING NOTES FROM TENNESSEE. \$1.25. THE FOOT-PATH WAY. $\$ 1.25$.

A RAMBLER'S LEASE. \$1.25.

A FLORIDA SKETCH BOOK. \$1.25.

A WORLD OF GREEN HILLS. \$1.25.

\section{HENRY D. MINOT}

THE LAND-BIRDS AND GAME-BIRDS OF NEW ENGLAND. 8 vo, $\$ 3.50$.

MRS. A. D. T. WHITNEY

BIRD-TALK. A Calendar in Verse of the Orchard and Wildwood. Illustrated. Crown 8vo, $\$ 1.00$.

HOUGHTON, MifFLIN \& CO., Boston.

11 East 17th Street, New York. 


$$
\text { . }
$$





$$
\text { . }
$$





\section{SMITHSONIAN INSTITUTION LIBRARIES}

